\title{
Prospective Efficient Ambient Energy Harvesting Sources for IoT-Equipped Sensor Applications
}

\author{
Mahmuda Khatun Mishu 1,2,*(D), Md. Rokonuzzaman 1,2,*他, Jagadeesh Pasupuleti 1,*, \\ Mohammad Shakeri ${ }^{1}{ }^{(0)}$, Kazi Sajedur Rahman ${ }^{3}{ }^{-}$, Fazrena Azlee Hamid ${ }^{2}$, Sieh Kiong Tiong ${ }^{1}$ \\ and Nowshad Amin ${ }^{1}$ \\ 1 Institute of Sustainable Energy (ISE), Universiti Tenaga Nasional (The National Energy University), \\ Kajang 43000, Selangor, Malaysia; mshakeri@uniten.edu.my (M.S.); siehkiong@uniten.edu.my (S.K.T.); \\ nowshad@uniten.edu.my (N.A.) \\ 2 College of Engineering (COE), Universiti Tenaga Nasional (The National Energy University), Kajang 43000, \\ Selangor, Malaysia; Fazrena@uniten.edu.my \\ 3 Solar Energy Research Institute, Universiti Kebangsaan Malaysia (The National University of Malaysia), \\ Bangi 43600, Selangor, Malaysia; sajed_cuet_eee@yahoo.com \\ * Correspondence: mahmuda.khatun@uniten.edu.my (M.K.M.); rokonuzzaman@uniten.edu.my (M.R.); \\ jagadeesh@uniten.edu.my (J.P.)
}

Received: 30 June 2020; Accepted: 10 August 2020; Published: 20 August 2020

\begin{abstract}
In the past few years, the internet of things (IoT) has garnered a lot of attention owing to its significant deployment for fulfilling the global demand. It has been seen that power-efficient devices such as sensors and IoT play a significant role in our regular lives. However, the popularity of IoT sensors and low-power electronic devices is limited due to the lower lifetime of various energy resources which are needed for powering the sensors over time. For overcoming this issue, it is important to design and develop better, high-performing, and effective energy harvesting systems. In this article, different types of ambient energy harvesting systems which can power IoT-enabled sensors, as well as wireless sensor networks (WSNs), are reviewed. Various energy harvesting models which can increase the sustainability of the energy supply required for IoT devices are also discussed. Furthermore, the challenges which need to be overcome to make IoT-enabled sensors more durable, reliable, energy-efficient, and economical are identified.
\end{abstract}

Keywords: internet of things (IoT); wireless sensor networks (WSNs); low-power electronic devices; IoT sensors; energy harvesting (EH); ambient energy sources

\section{Introduction}

Computational technology has been considered to be dynamic, adaptive, and well-connected for many decades. Kevin Ashton first coined the term 'internet of things (IoT)' in 1999 [1,2]. The concept of IoT is recognised as an important technological component of the newly emerging smart and computing world. The development of IoT components is based on its strong sensing and connective abilities. The IoT-equipped sensors and devices are used in wireless terminal of a network to collect data, information, and statistics from an ambient environment. IoT can be used in many applications, such as embedded systems [3-5], security surveillance systems [6-8], controllers [9-11], transportation systems [12-14], wearable devices [15-18], energy tracking [19], environmental monitoring systems [20-22], fire detection [23-25], object tracking [26-28], traffic monitoring [29-32], smart farming [33-35], human body area networking [36-39], etc. The commercial production of IoT devices has been increased significantly. By the end of 2020, $>26$ billion commercial devices are expected to be connected to the internet. This figure may also increase to $>100$ billion [40]. All IoT-based devices are tiny, 
and thus require a lower power supply for maintaining their functionality [41]. It is challenging to acquire a constant power supply for powering the devices, which can restrict the expansion of IoT field. The majority of IoT devices are installed in remote and inaccessible areas. This installation limits the use of traditional energy sources, making it difficult to power these devices [16,41-43]. Currently, batteries are seen as the main energy source for IoT devices. The use of batteries in remote areas might be challenging because of the issues related to the limited energy sources, ecological obstacles, shorter lifetime and maintenance of the batteries.

Energy harvesting $(\mathrm{EH})$ is considered to be an efficient solution for overcoming all of these limitations. EH refers to a process used to extract energy from various sources. Two different EH sources can be used: The first is external energy sources and the second is ambient energy sources. A ambient EH sources are generally present in the environment and require no external energy sources [44]. These include energy sources such as photovoltaic (PV) energy [45,46], vibration energy (VE) [47-50], heat energy [51,52], radio frequency (RF) [53,54], etc. Because of the diversity in the energy densities of ambient energy sources, hybrid energy harvesting systems (HEHSs) play a vital role in the IoT sector $[15,55,56]$. HEHS include $\geq$ two energy sources which can improve the performance and efficiency of the system $[57,58]$. In the case of IoT devices, the most common type of HEHS includes the micro-electro-mechanical system (MEMS) fabrication process. This is known as the miniature or micro-scale energy harvesting system $[59,60]$.

The remainder of the paper is presented in the following manner. Section 2 presents the motivation behind using energy harvesting systems in IoT devices. Section 3 describes the research trend of EH systems (EHSs), which is categorized into three classes, i.e., the EH concept, EH efficiency, and energy storage in EH systems. Section 4 describes the power needed for IoT devices and sensors. The EH in the IoT devices (EHIoT) is reviewed in Section 5, where fifteen different ambient energy sources and ambient transduction processes are briefly described. Section 6 presents the major challenges and a few recommendations. Section 7 lists some conclusions derived from this manuscript.

\section{The Motivation of Energy Harvesting in IoT}

Figure 1 presents the IoT timeline in infographics. In 1969, the first technical foundation of the internet, Advanced Research Projects Agency Network (ARPANET) was developed, pioneering existing internet-controlled devices. One of the first internet-connected devices was a 'vending machine', developed by the Carnegie Mellon University in 1982. In 1990, John Romkey invented the first internet-controlled device namely 'toaster' [61]. Kevin Ashton, who was a British innovator and executive director of the Auto-ID centre at the Massachusetts Institute of Technology (MIT), was the first to coin the term 'IoT'. In 2000, the first smart fridge was commercially developed by LG Electronics Inc. Google launched a self-driving car in 2009, while Google glass was launched in 2013. Google Nest is a smart home device that was developed and launched in 2010 by Google. Since 2017, artificial intelligence (AI), big data, and blockchain-integrated IoT devices have become popular across the world. Most of the enclosed systems, smart speakers, video cameras, sensors, meters, etc., have been connected to the internet and can be controlled very easily. However, many of these devices are wireless, sensor-based terminal devices, which are very small and thus cannot be easily accessed. Therefore, these IoT nodes can only be powered by using small batteries. This is not a very effective solution, since the installation of a battery in small sets is expensive and difficult and requires human labor. Under these scenarios, the development of $\mathrm{EH}$ technologies from ambient sources is an effective technique that can help to overcome the problems related to the powering of IoT-controlled devices [41]. 


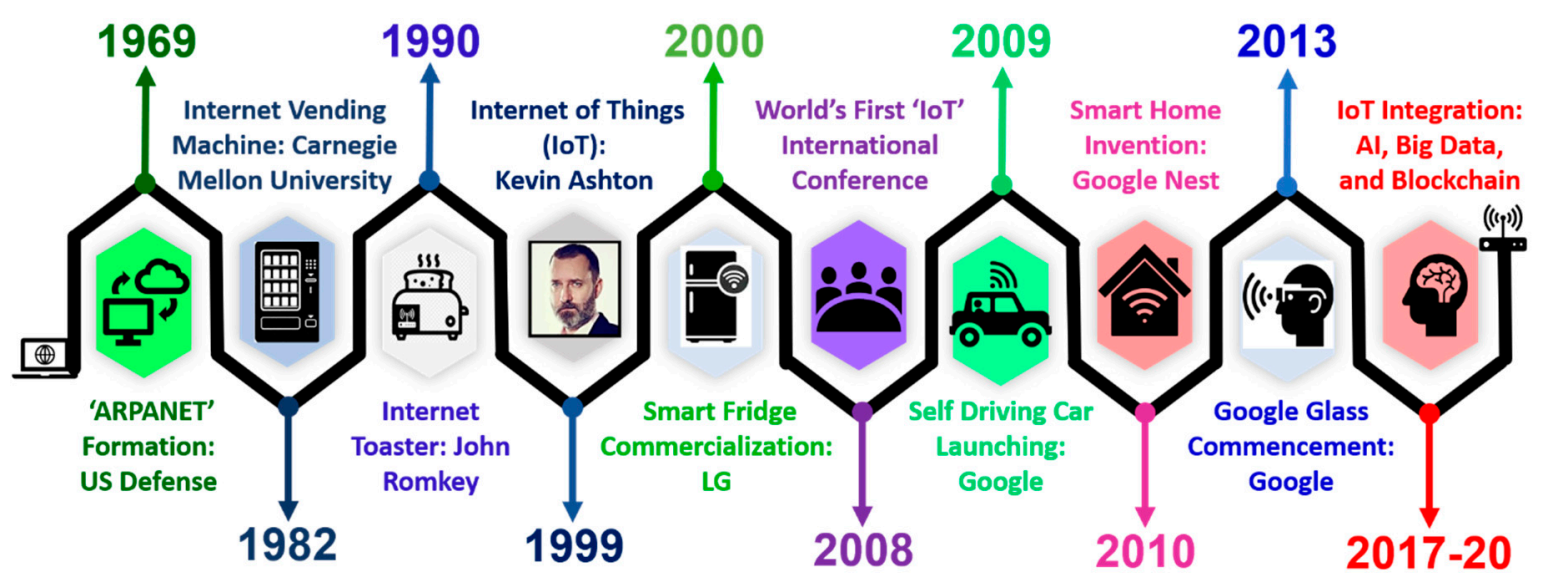

Figure 1. Internet of things (IoT) timeline in infographics (1969-2020).

\section{Research Trends in the EHS for IoT Devices}

There has been significant development in energy infrastructural systems. The computational ability of every energy supplier has been incorporated within the IoT sensors, which can increase their energy requirement. For overcoming this energy crisis, EHSs need to be developed which can enable the connection of IoT devices with a self-powered function. Many researchers have developed different techniques for mitigating the power requirements for upcoming and existing energy demands.

\subsection{Energy Harvesting (EH) Concepts}

The basic principle of energy sources was determined between 1821 and 1956. Figure 2 describes the primary EH timeline, which shows that the EH drift began in 1821, when Thomas Johann Seeback (T.J. Seebeck) described the thermoelectric effect. In 1839, Alexandre Edmond Becquerel (A. Edmond Becquerel) discovered the photovoltaic (PV) effect. Furthermore, in 1880, Jacques Curie (J. Curie) and Pierre Curie (P. Curie) discovered the piezoelectric effect. In 1931, Barnet Cohen invented the microbial fuel cell (MFC). Willium C. Brown determined the RF concept in 1950. In 1956, Henry Kolm determined the thermo-photovoltaic (Thermo-PV) effect. The mainstream EH trend was initiated in the mid-1990s, when researchers became more focused on self-sufficient energy techniques for electronic systems.

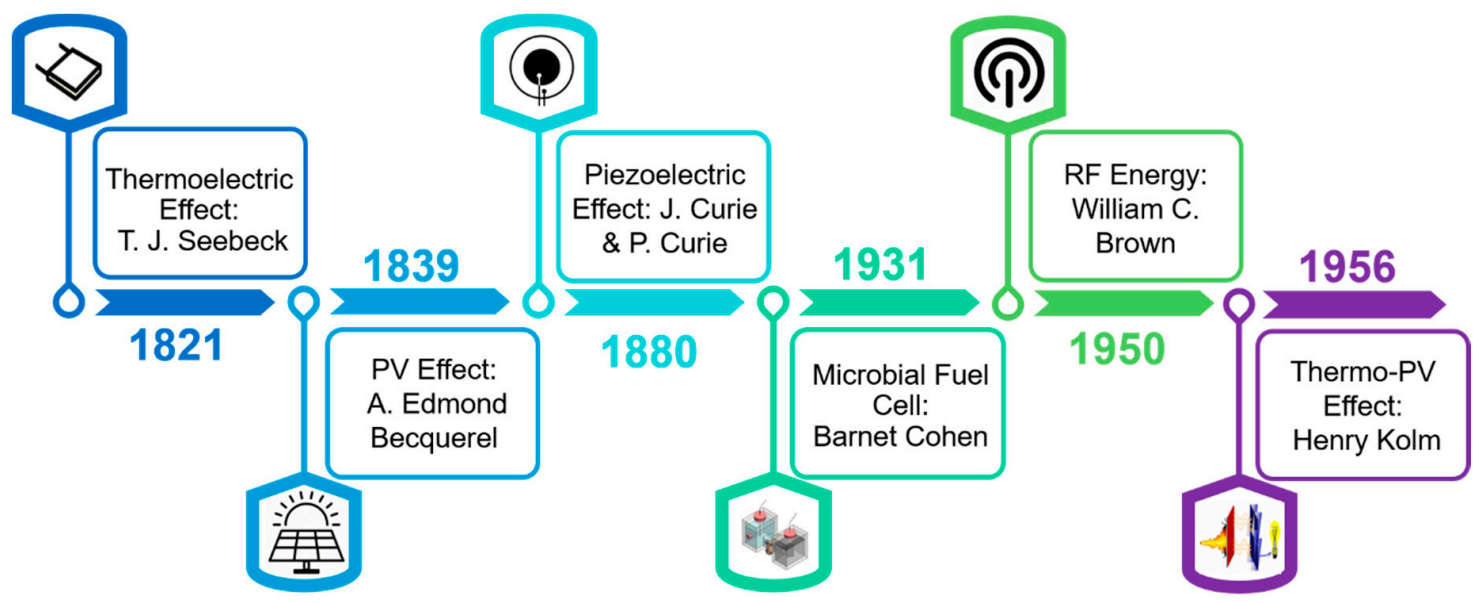

Figure 2. Basic energy harvesting (EH) timeline (1821-1956) [53,60,62].

\subsection{Energy Harvesting (EH) Efficiencies}

Kymissis et al. invented a piezoelectric converter which was stowed in an athletic shoe. This was the first example of an ecological energy harvester that was used for operating electronic devices [63]. 
Thereafter, research advanced significantly and was supported by the constant drop in the power consumption of integrated circuits (ICs). This led to a better research scope for self-powered electronic devices, such as wireless modules and battery replacements [64]. In the past few years, EHS based on a semiconductor and MEMS have gained much popularity in scientific and research fields $[65,66]$. The main motivation for this EH research was the miniaturization of EH systems on the microscale and their integration with dynamic electronics. This opened up a lot of research potential in microsystem and semiconductor technologies [67]. Khare et al. described different evolutionary algorithms and techniques which can be used in the wind and PV hybrid renewable energy system (HRES). The researchers determined the electric power generation efficiency based on the reliability issues, size optimization, feasibility analysis, climatic conditions, and dynamic performance [68]. Sinha et al. described different software tools such as SOLSTAR, improved hybrid optimization by genetic algorithms (iHOGA), hybrid optimization of multiple energy resources (HOMER), and Hybrid 2, which could be used for analysing the optimization of electrical energy for improving its generation and distribution. Software tools are seen to form an effective system which cost-effectively decreases the power intermittence problem. This may prove to be an environmentally-friendly and flexible system which could be used in the future. A software tool can be developed for improving the system performance based on the different control techniques, load management systems, economic balance, etc. This decreases system costs since the process is optimized [69]. Khan et al. described an HRES-reverse osmosis (HRES-RO) model, which used two energy sources, i.e., wind and PV, for improving the EH efficiency and decreasing the greenhouse gas emissions [70]. Kasseries et al. described a novel hybrid system which included a wind turbine (WT) and hydrogen fuel cell (HFC) for increasing the efficient use of the generated power [71]. Bernal-Agustin et al. also presented a simulation model that included various optimization techniques for wind HRES and a standalone PV for decreasing costs and improving the efficiency and reliability [72]. Liu et al. determined several novel non-volatile processor (NP)-based ambient EHSs with the help of a register allocation algorithm. This prototype and algorithm minimized the critical data overflow and improved the efficiency of the system [73].

\subsection{Energy Storage in EH Systems}

Bhandari et al. reviewed the optimization processes for the HRESs. Renewable and green energy sources such as hydro, wind, and PV have become popular renewable energy sources. When two or multiple energy sources are integrated and combined into one storage device, the system becomes more reliable. Different optimization techniques can be used, along with a few backup devices, such as battery banks or fuel cells, to make the system reliable and cost-effective [74]. Shivarma et al. described an HRES which included fuel cell, wind, and solar energies. They also used batteries and various magnetic and superconducting energy storage devices for increasing the reliability of the system [58]. Akan et al. developed a self-sufficient, batteryless system known as the internet of hybrid energy harvesting things (IoHEHT) for replenishing the battery power of all the electronic devices [42]. In another study, Shi et al. used the combination of a triboelectric nanogenerator (TENG) and flexible electronic technology for developing a micro-nano-system. The existing TENG and flexible electronic technologies made the system smarter and functional. These flexible wearable electronic devices allowed effective communication between the body and other multi-functional tools [59]. Perez-Collazo et al. reviewed a system wherein a combination of offshore wind and wave energies was used and optimized for decreasing the industrial costs. They studied the integration of the technologies and a substructure. This work focused on two aspects, i.e., wave to energy conversion and a substructure. This study also tested the sustainability, validity, and integration of the combined systems for determining the best technique combining the wave and offshore wind systems [75]. Del Real et al. presented a simulation model that included an optimization strategy for evaluating the optimal element sizing of the HES. Their system included hydrogen storage generators, wind data generators, and batteries. The total and optimized cost of this system was compared with a similar battery storage and hydrogen system. Their system improved the efficiency and investment 
costs [76]. Vosen et al. described a time-dependent model of the hybrid energy storage system (HESS). They compared the neural net control system (NNCS) with the general battery state-of-charge control structure, and noted that the NNCS showed a lower cost and was more efficient [77]. Garg et al. summarized the different types of EH and secondary storage system used in IoT devices. They stated that the EH systems could be used for increasing the life cycle and efficiency of IoT devices [78]. Kulatunga et al. described the theoretical computation model for off-loading in micro solar-powered EH systems for the WSN and other sensor devices [79]. Shao et al. developed a generic hill-climbing algorithm-based HSPICE simulation model for a micro-power management system. They used a $0.35 \mu \mathrm{m}$ complementary metal-oxide-semiconductor (CMOS) for verifying the control strategy [80]. Some of the earlier studies [81-84] highlighted the achievements of the EHS for small-scale power gains based on a material perspective. Based on the materials used in the devices, their major elements, and their energy harvesting benefits on a micro-scale, all results have been depicted in Table 1 .

Table 1. Achievements of material approaches for energy harvesting.

\begin{tabular}{|c|c|c|c|c|c|}
\hline Ref. & Year & Source & Materials Approaches & Advantages & Obtained Results \\
\hline [81] & 2007 & Thermoelectric & $\begin{array}{l}\text { ErAs:InGaAs/ } \\
\text { (InGaAs) (InAlAs) }\end{array}$ & $\begin{array}{l}\text { Thermodynamically steady } \\
\text { superlattice, augmented } \\
\text { thermopower coefficient, } \\
\text { lower electrical energy loss }\end{array}$ & $\begin{array}{l}2500 \mathrm{~mW} / \mathrm{cm}^{2} \\
(\text { at } 3.5 \mathrm{~V})\end{array}$ \\
\hline [82] & 2007 & Thermo-photovoltaic & $\begin{array}{l}\mathrm{p}-\mathrm{GaAs} / \mathrm{p}-\mathrm{Ge} / \mathrm{n}-\mathrm{Ge} \\
\text { cell structure }\end{array}$ & $\begin{array}{l}\text { Solid cell coat with } \\
\text { optimized bandgap energy, } \\
\text { permit high light } \\
\text { source absorbance }\end{array}$ & $\begin{array}{l}2.5 \mathrm{~W} / \mathrm{cm}^{2} \\
\text { (at } 3.5 \mathrm{~V}, 20 \mu \mathrm{m} \\
\text { thickness) }\end{array}$ \\
\hline [83] & 2008 & Piezoelectric & KNN/Mn/KCT material & $\begin{array}{l}\text { Lead-free, high curie } \\
\text { temperature, higher density, } \\
\text { and piezoelectric coefficient }\end{array}$ & $10,000 \mathrm{~mW} / \mathrm{cm}^{3}$ \\
\hline [84] & 2008 & Microbial FC & $\begin{array}{l}\text { Anode-cathode shallow } \\
\text { area distinction }\end{array}$ & $\begin{array}{l}\text { Smooth electron flow, } \\
\text { reduced inner resistance }\end{array}$ & $\begin{array}{l}6.86 \mathrm{~W} / \mathrm{m}^{2} \\
\left(\text { at } 2.62 \mathrm{~mA} / \mathrm{cm}^{2}\right)\end{array}$ \\
\hline
\end{tabular}

\section{Power Requirement of IoT Sensors and Devices}

While investigating the applications of IoT devices, one needs to understand the overall power densities which exist in the reference synopsis. The typical power densities are also categorized based on their energy source. Figure 3 presents a categorization of common devices based on their energy sources. As shown in Figure 3, IoT devices or low-powered electronic devices require power ranging between $10 \mathrm{nW}$ and $100 \mathrm{~W}$, also called small-scale energy. The typical power densities of these devices can be classified based on four main and existing energy sources, i.e., ambient light, vibrational/motion, thermal, and radio frequency (RF). Generally, the difference between the power densities and available energy sources can be easily overcome by efficiently harvesting natural energy.

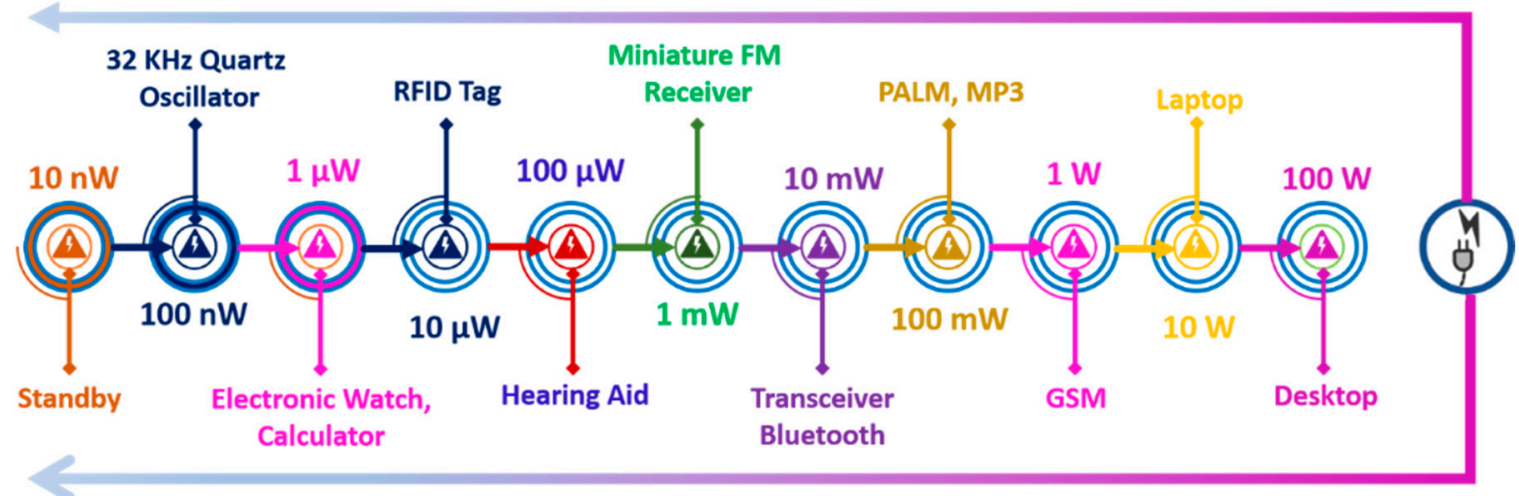

Figure 3. Power requirements of different IoT sensors and devices (10 nW-100 W) [85-88]. 
Table 2 lists the amount of power that can be harvested from popular and natural ambient energy sources. Ambient light energy sources allow the maximal amount of energy that can be harvested. However, the circumstances can differ between indoor and outdoor atmospheres, since the density of the harvested energy can easily vary between $10 \mathrm{~mW} / \mathrm{cm}^{2}$ and $10 \mu W / \mathrm{cm}^{2}$. This is comparable to vibrational or motion-based energy sources and thermal energy sources at a smaller scale, i.e., for human activities (4 and $30 \mu \mathrm{W} / \mathrm{cm}^{2}$, correspondingly). On the other hand, the power densities are harvested from the two energy sources and used for manufacturing applications $\left(100 \mu \mathrm{W} / \mathrm{cm}^{2}\right.$ and $1-10 \mathrm{~mW} / \mathrm{cm}^{2}$, correspondingly). However, RF energy is the minimal amount of energy that can be harvested $\left(0.1 \mu \mathrm{W} / \mathrm{cm}^{2}\right.$ for GSM $900 \mathrm{MHz}$ and $0.001 \mu \mathrm{W} / \mathrm{cm}^{2}$ for WiFi, respectively). The commercial macro-EHS generates about $100 \mathrm{~mW}$ of energy, which decreases to $1 \mathrm{~mW}$ in the case of miniaturized EHSs [64].

Table 2. Harvested power range from ambient sources [89].

\begin{tabular}{|c|c|c|c|c|}
\hline Energy Source & Characteristics & $\begin{array}{l}\text { Scavenging } \\
\text { Device }\end{array}$ & Power Density & Harvested Power \\
\hline Light & $\begin{array}{l}\text { Indoor } \\
\text { Outdoor }\end{array}$ & Solar Cell & $\begin{array}{l}0.1 \mathrm{~mW} / \mathrm{cm}^{2} \\
100 \mathrm{~mW} / \mathrm{cm}^{2}\end{array}$ & $\begin{array}{c}10 \mu W / \mathrm{cm}^{2} \\
10 \mathrm{~mW} / \mathrm{cm}^{2}\end{array}$ \\
\hline \multirow{2}{*}{$\begin{array}{l}\text { Vibration } \\
\text { or } \\
\text { Motion }\end{array}$} & Human & $\begin{array}{l}\text { Piezoelectric } \\
\text { Electrostatic }\end{array}$ & $\begin{array}{c}0.5 \mathrm{~m} \text { at } 1 \mathrm{~Hz} \\
1 \mathrm{~m} / \mathrm{s}^{2} \text { at } 50 \mathrm{~Hz}\end{array}$ & $4 \mu \mathrm{W} / \mathrm{cm}^{2}$ \\
\hline & Industry & $\begin{array}{c}\text { Piezoelectric } \\
\text { Electromagnetic }\end{array}$ & $\begin{array}{c}1 \mathrm{~m} \text { at } 5 \mathrm{~Hz} \\
10 \mathrm{~m} / \mathrm{s}^{2} \text { at } 1 \mathrm{kHz}\end{array}$ & $100 \mu \mathrm{W} / \mathrm{cm}^{2}$ \\
\hline Thermal & $\begin{array}{l}\text { Human } \\
\text { Industry }\end{array}$ & Thermoelectric & $\begin{array}{c}20 \mathrm{~mW} / \mathrm{cm}^{2} \\
100 \mathrm{~mW} / \mathrm{cm}^{2}\end{array}$ & $\begin{array}{c}30 \mu \mathrm{W} / \mathrm{cm}^{2} \\
1-10 \mathrm{~mW} / \mathrm{cm}^{2}\end{array}$ \\
\hline Radio Frequency & $\begin{array}{c}\text { GSM } 900 \mathrm{MHz} \\
\text { WiFi }\end{array}$ & Antenna & $\begin{array}{c}0.3 \mu \mathrm{W} / \mathrm{cm}^{2} \\
0.015 \mu \mathrm{W} / \mathrm{cm}^{2}\end{array}$ & $\begin{array}{c}0.1 \mu \mathrm{W} / \mathrm{cm}^{2} \\
0.001 \mu \mathrm{W} / \mathrm{cm}^{2}\end{array}$ \\
\hline
\end{tabular}

Figure 4 describes the intermittent amount of power that can be generated from some of the popular ambient energy sources. The power ranges from a minimum value of $0.1 \mu \mathrm{W}$ to a maximal amount of $<100 \mathrm{~W}$. A thermo-electric generator (TEG) can produce energy ranging from $10 \mu \mathrm{W}$ to $>100 \mathrm{~W}$, which can be used for many applications. EH from PV sources has become more popular in the past few years. This energy source generates a lot of energy, exhibiting from microwatt to megawatt (MW) ranges. However, this energy source is still being investigated, whereas RF sources show a limited production. These energy sources produce energy ranging between $0.1 \mu \mathrm{W}$ and $1 \mathrm{~mW}$. Furthermore, triboelectric energy has not been industrialized and is still under investigation. This energy source can generate energy ranging between $0.1 \mu \mathrm{W}$ and megawatt (MW) levels. On the other hand, piezoelectric energy generates a lot of power that ranges between $10 \mu \mathrm{W}$ and $100 \mathrm{~W}$. This form of energy can be widely industrialized.

\begin{tabular}{|c|c|c|c|c|c|c|c|c|c|c|c|}
\hline Power Range & $0.1 \mu W$ & $1 \mu W$ & $10 \mu \mathrm{W}$ & $100 \mu \mathrm{W}$ & $1 \mathrm{~mW}$ & $10 \mathrm{~mW} 100 \mathrm{~mW}$ & $1 \mathrm{~W}$ & $10 \mathrm{~W}$ & $100 \mathrm{~W}$ & $<100 \mathrm{~W}$ & Industrialization \\
\hline \multirow{6}{*}{ 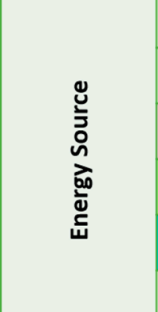 } & \multicolumn{10}{|c|}{ Thermoelectric Generator (TEG) } & Widespread Production \\
\hline & \multicolumn{10}{|c|}{ Photovoltaic (PV) Energy } & Widespread Production \\
\hline & \multicolumn{5}{|c|}{ Pyroelectric Energy } & & & & & & Research Stage \\
\hline & \multicolumn{5}{|c|}{ Radio Frequency (RF) Waves } & & & & & & Limited Production \\
\hline & \multicolumn{10}{|c|}{ Triboelectric Energy } & Research Stage \\
\hline & & & \multicolumn{7}{|c|}{ Piezoelectric Energy } & & Widespread Production \\
\hline
\end{tabular}

Figure 4. Intermittent amount of power that is generated from common ambient energy sources [90].

Table 3 describes IoT devices and sensors, along with the different EHSs. PV energy is considered to be the best form of energy and hence is used in the majority of IoT applications, such as healthcare, smart homes or buildings, wearable devices, vehicles, and industries. Wind energy is also used in 
many smart buildings, smart homes, and smart cities. Furthermore, electromagnetic induction (EMI) is used for outdoor lighting, sensors, and many healthcare applications. A TEG is best suited to smart buildings, industrial devices, or sensors.

Table 3. IoT applications and the different EH systems (EHSs) [91].

\begin{tabular}{|c|c|c|c|c|c|}
\hline \multicolumn{2}{|c|}{ IoT Sensors/Applications } & \multicolumn{4}{|c|}{ Energy Harvesting Ambient Sources } \\
\hline & & PV & Wind & EMI * & TEG \\
\hline \multirow{6}{*}{$\begin{array}{l}\text { Smart Building, } \\
\text { Smart Home }\end{array}$} & Lighting & $\bullet$ & $\bullet$ & $\bullet$ & \\
\hline & Air Quality Monitor & $\bullet$ & $\bullet$ & & \\
\hline & Surveillance Camera & $\bullet$ & $\bullet$ & & \\
\hline & Smart Door Lock & $\bullet$ & & & \\
\hline & Smart Thermostat & $\bullet$ & $\bullet$ & & $\bullet$ \\
\hline & Outdoor Sensor & $\bullet$ & $\bullet$ & $\bullet$ & $\bullet$ \\
\hline \multirow{2}{*}{ Wearable } & Smart Watch & $\bullet$ & & & \\
\hline & Tracking & $\bullet$ & & & \\
\hline \multirow{2}{*}{ Fitness } & Medical Patch & $\bullet$ & & $\bullet$ & \\
\hline & Fitness Band & $\bullet$ & & & \\
\hline \multirow{2}{*}{ Industry } & Automation & $\bullet$ & & & $\bullet$ \\
\hline & Machine Monitor & $\bullet$ & & & $\bullet$ \\
\hline Vehicles & Vehicle Tracker & • & & & \\
\hline
\end{tabular}

Table 4 presents a comparison of the EH process from various ambient sources. This analysis has been divided into general ambient sources, features, the power density, the conversion efficiency $(\mathrm{CE})$, the energy handiness (EH), the harvester, advantages, and disadvantages. Based on the features, the energy sources were further categorized into ambient $(\mathrm{A})$, controllable $(\mathrm{C})$, partly controllable (PC), uncontrollable (UC), predictable (P), partly predictable (PP), unpredictable (UP), and passive human power (PHP). The natural ambient sources are seen to be outdoor and indoor solar energy, wind, thermal energy, motion, vibration, RF, airflow, magnetic field (M-Field), electric field (E-Field), and MFCs. On the other hand, the human-dependent ambient energy sources are seen to be breathing (Br.), exhalation (Ex.), finger motion (FM), footfalls (FF), and blood pressure (BP). The results shown in Table 4 indicate that PV cells can generate $10-100 \mathrm{~mW} / \mathrm{cm}^{2}$ power, i.e., $16-17 \%$ CE from the direct outdoor sunlight or artificial indoor lighting (Art. light). PV cells can generate $10-100 \mu W / \mathrm{cm}^{2}$ power using a similar conversion rate. However, the PV energy can be seen to be ambient and predictable, but uncontrollable. 
Table 4. Comparative analysis of energy harvesting systems based on different ambient energy sources.

\begin{tabular}{|c|c|c|c|c|c|c|c|c|}
\hline References & ES * & Features * & $\mathrm{EH}^{*}$ & Harvester * & $\mathrm{CE}^{*}$ & Power Density * & Advantages * & Disadvantages * \\
\hline$[42,78,91,92]$ & $\begin{array}{l}\text { Sun Light } \\
\text { (Outdoor) }\end{array}$ & A, UC, P & Fair & PV Cell & $16-17 \%$ & $10-100 \mathrm{~mW} / \mathrm{cm}^{2}$ & High output voltage & Unavailable at night \\
\hline$[42,78,91,92]$ & $\begin{array}{l}\text { Art. Light } \\
\text { (Indoor) }\end{array}$ & A, UC, P & Fair & PV Cell & $16-17 \%$ & $10-100 \mu \mathrm{W} / \mathrm{cm}^{2}$ & High output Voltage & Low conversion rate \\
\hline$[42,78,91,92]$ & $\begin{array}{l}\text { Wind } \\
\text { (Outdoor) }\end{array}$ & A, UC, P & Good & WG & - & $3.5 \mathrm{~mW} / \mathrm{cm}^{2}$ Speed $\leq 8.4 \mathrm{~m} / \mathrm{s}$ & Available (D\&N) & Unavailable in CA \\
\hline$[42,78,91,92]$ & $\begin{array}{l}\text { Wind } \\
\text { (Indoor) }\end{array}$ & A, UC, P & Good & WG & - & $\begin{array}{l}35 \mu \mathrm{W} / \mathrm{cm}^{2} \\
\text { Speed }<1 \mathrm{~ms}\end{array}$ & Available (D\&N) & Unavailable in CA \\
\hline$[42,78,92]$ & Motion & $\mathrm{C}, \mathrm{PP}$ & Fair & Piezoelectric & - & $200 \mu \mathrm{W} / \mathrm{cm}^{2}$ & Lightweight & Highly variable output \\
\hline$[42,78,92]$ & Thermal & $\mathrm{A}, \mathrm{UC}, \mathrm{P}$ & Poor & Thermocouple & $\leq 1 \%$ for $\Delta \mathrm{T}<40 \%$ & $\cong 60 \mu \mathrm{W} / \mathrm{cm}^{2}$ at $\Delta \mathrm{T}=5^{\circ} \mathrm{C}$ & $\begin{array}{l}\text { Reliable, longer life, } \\
\text { low maintenance }\end{array}$ & $\begin{array}{l}\mathrm{NP} \text {, low energy } \\
\text { conversion efficiency }\end{array}$ \\
\hline [78] & Vibration & A, C, P & Poor & EMI & - & $0.2 \mathrm{~mW} / \mathrm{cm}^{2}$ & No voltage source & Brittle material \\
\hline$[48,78,93]$ & $\mathrm{RF}$ & PP, PC & Good & Rectennas & - & $1 \mu \mathrm{W} / \mathrm{cm}^{2}$ & $\begin{array}{l}\text { Enough in urbanized } \\
\text { zone, permit mobility }\end{array}$ & $\begin{array}{l}\text { Distance dependent, } \\
\text { low power density }\end{array}$ \\
\hline$[42,93-95]$ & Airflow & A, UC, UP & Fair & $\begin{array}{l}\text { Anemometer, } \\
\text { Piezo turbines }\end{array}$ & - & $100 \mathrm{~mW} / \mathrm{cm}^{2}$ & $\begin{array}{l}\text { Independent of grid, } \\
\text { available (D\&N) }\end{array}$ & $\begin{array}{l}\text { Fluctuating density, } \\
\text { tough to implement }\end{array}$ \\
\hline$[92,96]$ & FM & $\mathrm{C}, \mathrm{P}$ & Fair & Piezoelectric & $11 \%$ & $2.1 \mathrm{~mW}$ & Available & Variable, NP \\
\hline [92] & Footfalls & $\mathrm{C}, \mathrm{P}$ & Fair & Piezoelectric & $7.5 \%$ & $5 \mathrm{~W}$ & Available & Highly variable, NP \\
\hline$[92,96]$ & Breathing & $\mathrm{UC}, \mathrm{UP}$ & Good & $\mathrm{R}-\mathrm{F}$ & $50 \%$ & $0.42 \mathrm{~W}$ & Available & Non-periodic \\
\hline$[42,93,94]$ & M-Field & $\mathrm{C}, \mathrm{P}$ & Good & $\mathrm{CT}$ & - & $150 \mu \mathrm{W} / \mathrm{cm}^{3}$ & Easy to implement & High current flow \\
\hline$[42,93,94]$ & E-Field & $\mathrm{C}, \mathrm{P}$ & Good & Metallic plates & - & $17 \mu \mathrm{W} / \mathrm{cm}^{3}$ & SD, available & Mechanical constraints \\
\hline [92] & Exhalation & UC, UP & Good & Breath mask & $40 \%$ & $0.4 \mathrm{~W}$ & Low efficiency & Non-periodic \\
\hline$[92,96]$ & BP & PHP, UC, UP & Good & MG & $40 \%$ & $0.37 \mathrm{~W}$ & Low efficiency & Non-periodic \\
\hline [97] & MFC & & Fair & Fuel cell & - & $10 \mu \mathrm{W}-2 \mathrm{~mW}$ & $\mathrm{NH}$, used in biosensor & Low output voltage \\
\hline
\end{tabular}

* Energy sources (ES), energy handiness (EH), conversion efficiency (CE), ambient (A), controllable (C), uncontrollable (UC), partly controllable (PC), predictable (P), partly predictable (PP), unpredictable (UP), passive human power (PHP), wind generator (WG), electromagnetic induction (EMI), blood pressure (BP), microbial fuel cell (MFC), Ratchet-Flywheel (R-F), current transformer (CT), micro generator (MG), finger motion (FM), magnetic field (M-Field), electric field (E-Field), Day \& Night (D\&N), simple design (SD), closed area (CA), non-hazardous (NH), and non-periodic (NP). 
On the other hand, when the wind speeds are $\leq 8.4 \mathrm{~m} / \mathrm{s}$, a wind generator can harvest around $3.5 \mathrm{~mW} / \mathrm{cm}^{2}$ energy under outdoor conditions or around $35 \mu \mathrm{W} / \mathrm{cm}^{2}$ energy when the wind speed is less than $1 \mathrm{~m} / \mathrm{s}$ in an indoor environment. Furthermore, a piezoelectric generator produces $200 \mu \mathrm{W} / \mathrm{cm}^{2}$ energy from different motions. The motion-based energy is partly predictable and controllable. A thermocouple harvests $\cong 60 \mu \mathrm{W} / \mathrm{cm}^{2}$ at $\Delta \mathrm{T}=5{ }^{\circ} \mathrm{C}$ power using thermal energy sources at an efficiency of $\leq 1 \%$ when $\Delta \mathrm{T}<40 \%$. The thermal energy is ambient and predictable; however, it is uncontrollable. EMI sources generate $0.2 \mathrm{~mW} / \mathrm{cm}^{2}$ energy using vibrational energy sources. This type of energy is predictable, ambient, and controllable; however, the material used is brittle. The RF energy sources are partly predictable and partly controllable. Airflow produces $100 \mathrm{~mW} / \mathrm{cm}^{2}$ energy using the piezo turbines and an anemometer. Implementing an ambient airflow is uncontrollable, difficult, and unpredictable. Furthermore, finger motions or footfalls can be seen to be a controllable form of energy source, which produce $2.1 \mathrm{~mW}$ and $5 \mathrm{~W}$ energy, respectively, using a piezoelectric energy harvester. The FM source displays an $11 \% \mathrm{CE}$, while the FF shows a $7.5 \%$ CE. A Ratchet-Flywheel (R-F) can be used for extracting energy from the breathing process, with a $50 \% \mathrm{CE}$. It generates $0.42 \mathrm{~W}$ of energy. The amount of breathing energy that is harvested is uncontrollable and unpredictable. A current transformer (CT) is used for harnessing energy from the magnetic field. This form of energy is predictable and controllable and generates $150 \mu \mathrm{W} / \mathrm{cm}^{3}$ power. A higher current requirement restricts the application and expansion of the M-Field energy harvester. Furthermore, it can be seen that an electric field produces $17 \mu \mathrm{W} / \mathrm{cm}^{3}$ energy using a metallic plate energy harvester. Human-based parameters such as the blood pressure and exhalation produce $40 \%$ energy with the help of a microgenerator and breath mask, respectively. The exhalation process can generate $0.4 \mathrm{~W}$ energy, while BP generates $0.37 \mathrm{~W}$. The MFC can produce $10 \mu \mathrm{W}-2 \mathrm{~mW}$ energy and is generally used in many biosensors.

\section{Energy Harvesting in IoT (EHIoT)}

EHIoT includes several common energy sources, along with a few transduction techniques (TT). Figure 5 describes the EHIoT taxonomy that can be categorized into two classes, i.e., ambient-based and human body-based. The ambient-based EHIoT is further categorized into ten different sub-categories. The popular ambient-based EHIoT include PV energy, thermal energy, piezoelectric mechanical vibration (MV) energy, pyroelectric energy, triboelectric MV energy, EMI-MV energy, microbial fuel cell (MFC) energy, radio frequency (RF), wind energy (WE), and acoustic energy (AE). On the other hand, existing wearable technologies which are based on the human-centered EHIoT include finger motion (FM), footfalls (FF), breathing (Br.), exhalation (Ex.), and blood pressure (BP).

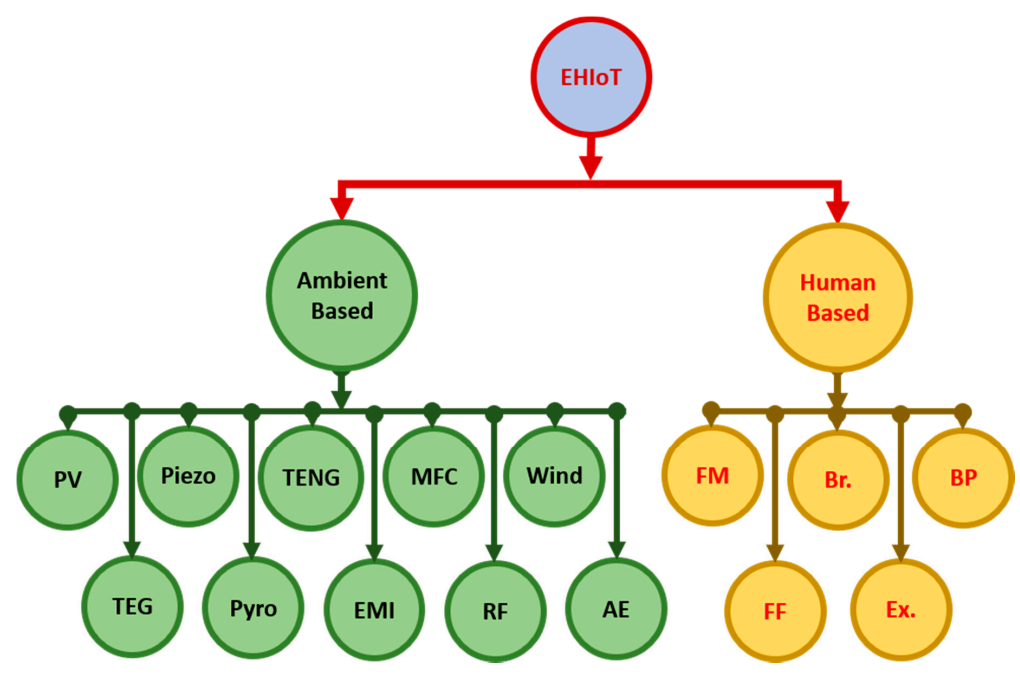

Figure 5. Taxonomy of energy harvesting in IoT (EHIoT). 


\subsection{Ambient Energy Sources}

Ambient energy sources can be naturally or artificially present in the environment. Various factors are related to the productivity of these energy sources [98]. The following subsections discuss effective and popular ambient energy sources.

\subsubsection{PV or Solar Energy}

Solar energy is one of the most popular green energy sources, according to the 2018 report published by the International Renewable Energy Agency (IRENA) [99]. It is naturally present in abundant quantities and is an affordable form of green energy which can decrease the energy demands in the IoT area. Sunlight can be converted to usable energy with the help of thermal conversion (TC) and photovoltaic conversion (PVC) processes. In TC, sunlight can be converted into electric energy after the medium is warmed and the heat energy passes through the turbine generator. In PVC, the light energy is converted into electric energy. It does not require any intermediary energy transformation steps or moving components. On a sunny day, sunlight offers the highest power density of $\approx 10$ and $100 \mathrm{~mW} / \mathrm{cm}^{2}$, which makes solar energy harvesting a promising process for developing IoT sensor applications [42,78,91,92,100-103]. Figure 6a describes the photovoltaic effect. Whenever sunlight becomes incident on a p-n junction layer, the charges that are produced are separated by the electron-hole pairs and are transmitted to electrodes. Assuming that the short circuit current is represented by $I_{s c}$, the saturation current is $I_{0}$, the diode ideality constant refers to $a$, series-connected cells are represented by $N_{s}, T$ denotes the temperature of a PN junction, the Boltzman constant is $K=1.38 \times 10^{-23} \mathrm{~J} / K$, the electric charge on the electron is $q=1.6 \times 10^{-19} \mathrm{C}, R_{S}$ denotes the series resistance, and $R_{s h}$ refers to the shunt resistance of a solar cell. Thereafter, the output current is determined as

$$
I=I_{S C}-I_{o}\left[\exp \left(\frac{V+R_{S} I}{\frac{N_{s} K T}{q} a}\right)-1\right]-\left(\frac{V+R_{S} I}{R_{s h}}\right)
$$

If the thermal voltage of an array $V_{t}=\frac{N_{s} K T}{q}$, Equation (1) is rewritten as

$$
I=I_{s c}-I_{o}\left[\exp \left(\frac{V+R_{S} I}{V_{t} a}\right)-1\right]-\left(\frac{V+R_{S} I}{R_{s h}}\right)
$$

\subsubsection{Thermoelectric Generator (TEG)}

According to the Seebeck effect, smaller temperature differences occurring across p-type and n-type materials can generate an electron flow. A TEG converts heat energy into electric energy. With regards to the thermal properties of a device, the power efficiency is based on its Seebeck coefficient $[60,104,105]$. Figure $6 \mathrm{~b}$ describes the operating principles of a TEG. If the output voltage in a TEG is represented by $V_{T}$, the temperature difference is indicated by $\Delta T$ and the Seebeck coefficient is $\alpha$. Therefore, the output voltage in TEG is represented by Equation (3).

$$
V_{T}=\alpha \Delta T
$$

Furthermore, the thermoelectric material figure of merit is represented as ZT and is determined as follows:

$$
Z T=\frac{\sigma \alpha^{2} T}{K_{e}+K_{1}}
$$

where $\sigma$ is the electrical conductivity, $T$ is the average operating temperature, $K_{e}$ the electronic-contributed thermal conductivity, and $K_{1}$ is the lattice-contributed thermal conductivity. 


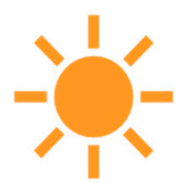

(a)

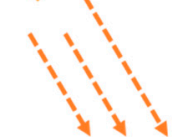

Electrode

\section{P-Type Material}

N-Type Material Electrode

(c)
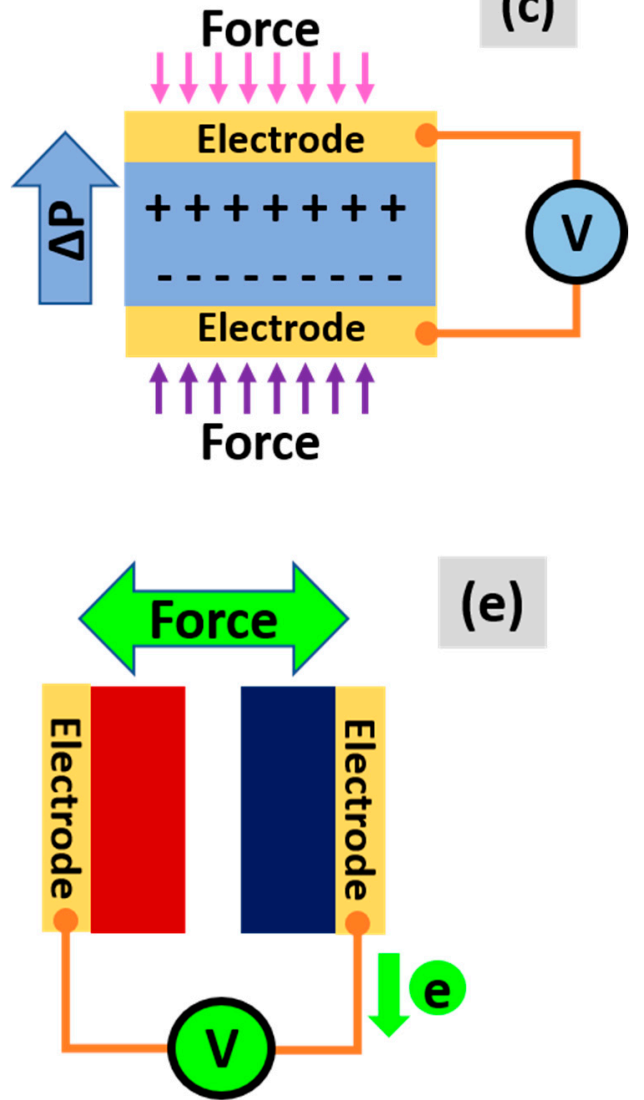

(b)

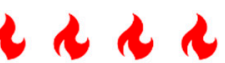

\section{Hot Surface}
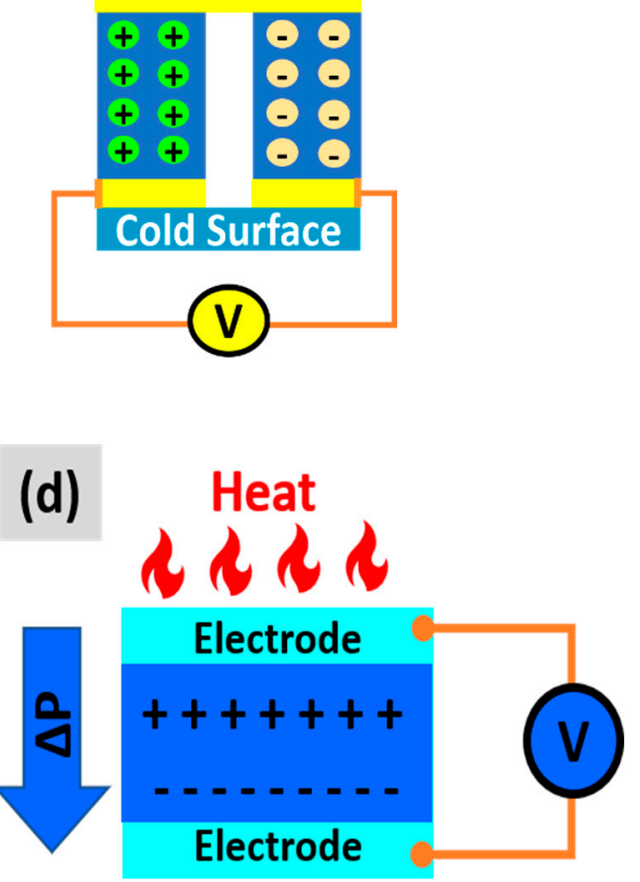

(f)

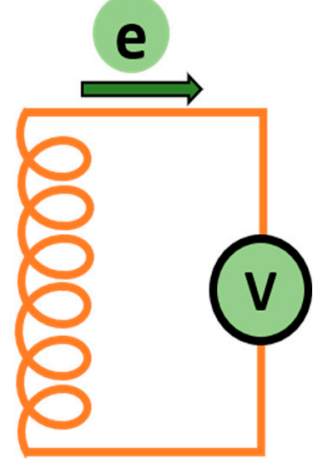

Figure 6. A schematic diagram representing various EH systems, where (a) photovoltaic EH, (b) thermoelectric $\mathrm{EH}$, (c) piezoelectric $\mathrm{EH},(\mathbf{d})$ pyroelectric $\mathrm{EH}$, (e) triboelectric $\mathrm{EH}$, and (f) electromagnetic induction $\mathrm{EH}$.

\subsubsection{Piezoelectric Effect}

J. Curie and P. Curie determined the concept of piezoelectricity in 1880 [106]. In 1881, Lippmann and the Curie siblings also determined the converse piezoelectric effect [107]. This helped in the establishment of a two-way conversion between electrical and mechanical energies. The piezoelectric effect can be described as the mutual coupling of electrical variables, such as an electrical field, and mechanical variables, such as the mechanical strain, mechanical stress, etc. $[2,32,47,108,109]$. The mechanical energy is converted into electrical energy as it uses a symmetrical crystal structure. 
Figure $6 c$ describes the piezoelectric function. Equation (5) represents the polarization charges acquired by a piezoelectric material.

$$
\rho_{p}=d_{p} X
$$

Here, $\rho_{p}$ is the polarization charge density, $d_{p}$ is the piezoelectric coefficient, and $X$ is the external strain or force.

\subsubsection{Pyroelectric Effect}

In 2012, Wang et al. [110,111] developed the first pyroelectric nanogenerator, presented in Figure 6d. This pyroelectric generator refers to a thermal-based source of energy. Spontaneous polarization noted at variable temperatures generates electricity based on the pyroelectric properties. Therefore, $P_{\text {pyro, }}$ which is the pyroelectric coefficient, is described as

$$
P_{\text {pyro }}=\frac{d \rho}{d T}
$$

The spontaneous polarization is represented by $\rho$, while $T$ denotes the temperature. The induced charge is $Q, \mu$ is the absorption coefficient, and $A$ is the surface area. Thereafter, the pyroelectric output current is described using the equation below:

$$
I=\frac{d Q}{d T}=\mu P_{p y r o} A \frac{d T}{d t}
$$

\subsubsection{Triboelectric Effect}

In 2012, Fan et al. developed the triboelectric nanogenerator (TENG) [45,112]. TENG was seen to be a mechanical energy-related source of energy which was based on electrostatic and triboelectrification induction [113]. The major triboelectric properties are based on its surface charge density. Figure 6e describes the triboelectric effect. Equation (8) denotes the triboelectric potential, $V_{T}$, as follows:

$$
V_{T}=-\frac{\rho_{T} d}{\varepsilon_{0}}
$$

Here, $\rho_{T}$ is the triboelectric charge density, $\varepsilon_{0}$ is the vacuum permittivity, and $d$ is the gap distance between two triboelectric materials. Therefore, the triboelectric current, $I_{T}$, is denoted as follows:

$$
I_{T}=\frac{\partial}{\partial t}\left(C_{T} V_{T}\right)=C_{T} \frac{\partial V_{T}}{\partial t}+V_{T} \frac{\partial C_{T}}{\partial t}
$$

where $C_{T}$ is the capacitance and $V_{T}$ is the voltage.

\subsubsection{Electromagnetic Induction (EMI)}

Two different researchers, Michael Faraday and Joseph Henry, determined the electro motive force (EMF) independently. EMF is induced by changing the magnitude of the magnetic field and the magnetic flux [114]. EMI can harness the energy from the MV energy sources, wherein the magnets and conductors are seen to be important components. Mechanical displacement from artificial or natural objects, such as human movements or wind flow, becomes the major driving force of an EMI [115]. In one study, the researchers developed three types of electromagnetic energy harvesting system (EMEHS) [116]. The first was the linear EMEHS, which was interfaced with a pure resistive electrical load [117]. The second included a non-linear EMEHS that was connected to the linear circuit [118]. The third included the linear EMEHS, which was connected to the non-resistive electrical load [119]. 
Figure $6 \mathrm{f}$ describes the EMI functions. A magnetic flux is denoted as $\Phi_{\mathrm{B}}$ and EMF is represented as $\varepsilon_{\text {emg. }}$. Therefore, the EMI voltage is expressed as follows:

$$
\varepsilon_{e m g}=-N \frac{d \varphi_{B}}{d t}
$$

where $N$ is the coil turn number.

\subsubsection{Microbial Fuel Cells (MFCs)}

In addition to the different energy resources, MFCs are also regarded as a major energy harvester. In 1931, Barnet Cohen carried out primary experiments using the MFC $[60,84]$. The MFC is considered to be a bio-electrochemical transducer which is generally used for wastewater treatment, in biosensors, and for producing hydrogen fuel. MFCs make use of potential anaerobic bacteria which respire, oxidize, and conduct electrons in the system [120-123].

\subsubsection{Radio Frequency (RF)}

Radio frequency (RF) EHS is a popular passive energy extraction technique. RF identification (RFID) tags or RF tags are popular devices powered by RF propagation [124]. The RF energy harvesting process is a prospective source of energy as it generates a lower power. These tags are helpful in IoT sensors as the IoT nodes require a lower power [54,91,125].

\subsubsection{Wind Energy Harvesting}

After solar energy, wind energy is considered to be the best green energy source in the world [99]. This form of energy is being investigated for powering remote wireless monitoring systems. The wind flow is natural and is also seen to be a vibrational energy source. The vibrations of the wind are based on the velocity of the wind flow. Some researchers have used adaptable piezoelectric devices for extracting energy from a constant oscillatory vibration of the wind flow [126-128]. In the cross-sectional area between the EH devices and the wind flow, the cross-sectional area is $A \mathrm{~m}^{2}$, wind flow density is $\rho \mathrm{kg} / \mathrm{m}^{3}$, and wind velocity is $V \mathrm{~m} / \mathrm{s}$. Therefore, the amount of power available is determined as follows [127]:

$$
P=\frac{1}{2} A \rho V^{3}
$$

\subsubsection{Acoustic Energy Harvesting (AEH)}

Acoustic energy harvesting (AEH) or the sound EH (SEH) process is a new technological advancement which is being investigated due to the abundance of clean sound waves. The majority of sound waves are semi-permanent and can become a significant alternative source of energy for IoT-based wireless sensor networks (WSNs) $[128,129]$. Vibrational or sound waves can propagate energy in the form of sound or acoustic energy. The receiver harnesses this propagated energy and converts the vibrational energy into electrical energy. This conversion is generally facilitated by the piezoelectric effect [130]. Figure 7 presents a schematic design of the AEH. The AEH system usually consists of a resonator, a membrane, and piezoelectric materials. The sound oscillations are produced by a resonator with the help of a resonant frequency. A membrane is placed between the resonator and piezoelectric material. Lastly, the piezoelectric material converts mechanical energy into electrical energy. 


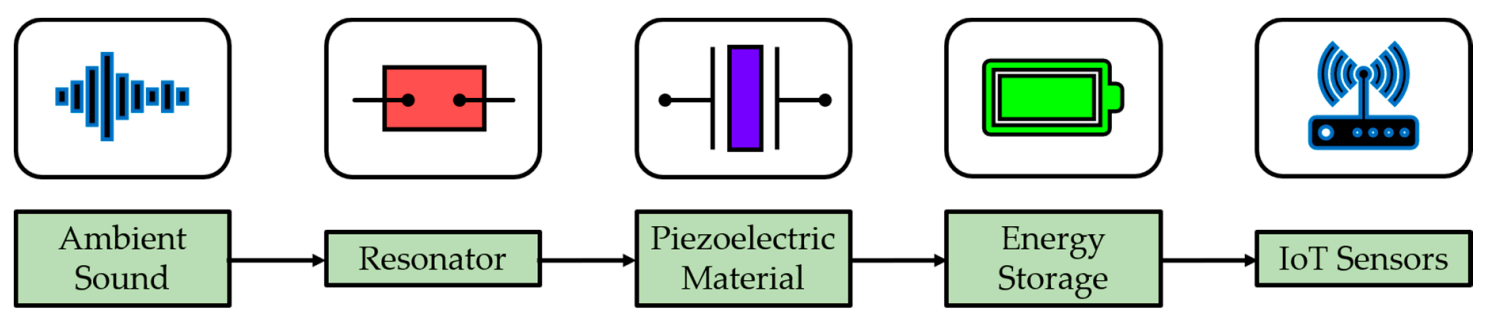

Figure 7. A schematic design of a general acoustic energy harvesting (AEH) system.

\subsection{Human-Based Energy Harvesters}

Energy can be generated from the human body in different ways, such as through finger motions, footfalls, breathing, blood pressure, etc. In the past few years, a wireless body area network (WBAN) has been used for deploying various sensors for monitoring human organs [39]. Figure 8 describes the amount of energy that is harvested from a human body. Table 5 lists a comparison of the available power and the minimal usable power that can be harvested from a body. A few EHS derived from the human body have been reviewed here.

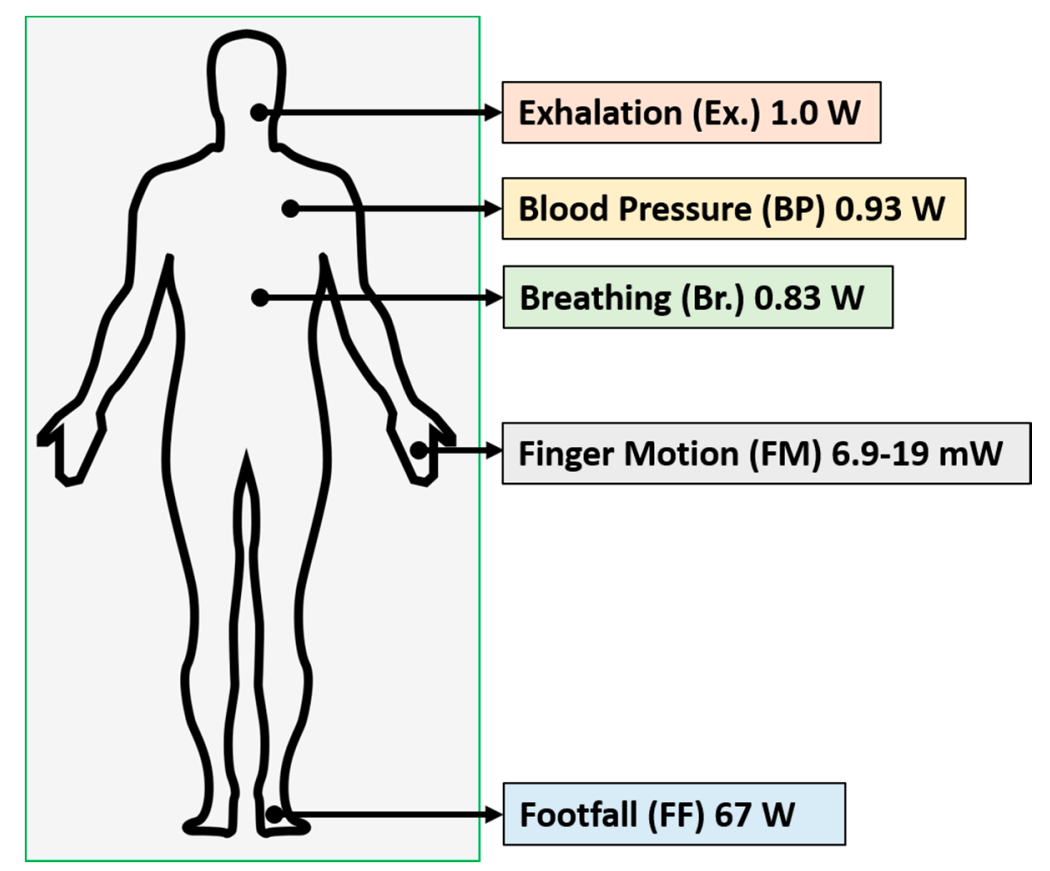

Figure 8. Different EHS that can be developed from a human body.

Table 5. A summary of the power generated from human body-driven sources (HBDS).

\begin{tabular}{ccc}
\hline HBDS & Available Power & Usable Power \\
\hline Finger Motion & $6.9-19 \mathrm{~mW}$ & $0.76-2.1 \mathrm{~mW}$ \\
\hline Breathing & $0.83 \mathrm{~W}$ & $0.42 \mathrm{~W}$ \\
\hline Footfall & $67 \mathrm{~W}$ & $5.0-8.3 \mathrm{~W}$ \\
\hline Exhalation & $1.0 \mathrm{~W}$ & $0.40 \mathrm{~W}$ \\
\hline Blood Pressure & $0.93 \mathrm{~W}$ & $0.37 \mathrm{~W}$ \\
\hline
\end{tabular}

The finger motions (FM) can be seen to be effective energy sources for IoT sensors. It can be seen that for the Handy Key's Twiddler keyboard, a $130 \mathrm{~g}$ finger pressure was needed for pressing the button, which helps in generating $\approx 6.9 \mathrm{~mW}$ power. In the case of a QWERTY keyboard, $40-50 \mathrm{~g}$ of pressure is 
needed for producing $19 \mathrm{~mW}$ power [96]. An average person, who weighs $68 \mathrm{~kg}$, produces $324 \mathrm{~W}$ power when taking two footsteps per second. The basic fall of a heel generates $67 \mathrm{~W}$ power on a $5 \mathrm{~cm}$ space [96]. Furthermore, energy can also be harvested from the breathing function. This requires an external mask. A few professionals, such as military aircraft pilots, astronauts, etc., can harness a lot of energy from masks which are used in the services. Breathing helps in generating $0.83 \mathrm{~W}$ power when a band is tightened around their chest [96]. A person who weighs $68 \mathrm{~kg}$ requires $\approx 30 \mathrm{~L}$ of air every minute while breathing. Therefore, $1 \mathrm{~W}$ of energy can be harvested during exhalation [96]. It may seem that it is not possible to harness energy from the blood pressure; however, a person with a normal $\mathrm{BP}(100 \mathrm{~mm}$ of $\mathrm{Hg})$ produces $0.93 \mathrm{~W}$ energy/min [96].

\section{Challenges and Recommendations}

Due to the decrease in traditional energy sources, many EH mechanisms have been initiated. Additional power generation is also desirable, since there has been an increase in the number of IoT sensors and devices. However, it is not easy to maintain the level due to the various power sources and an increase in the IoT sector. Most of the ambient energy sources have a low power efficiency and are unable to transmit or distribute the harvested energy to the IoT sensor nodes. Therefore, the transduction processes and EH efficiency must be improved. The wide bandwidth and the stochastics of the ambient energy sources can complicate the designs of miniaturized EH systems. Out of the different ambient EHS, the vibration EH (VEH) and the human body-based EH (HBEH) systems have a lower output and efficiency. Since the demand for micro-scale power generation systems is increasing, more reliable and cost-effective transduction techniques need to be developed for fabricating the $\mathrm{VEH}$. The $\mathrm{EH}$ processes must also take into consideration the diversity of the flexible demands made by the user and the impact of an unpredicted emergency that can arise in harsh environmental conditions. Therefore, a robust EH model and central energy harvesting network (CEHN) should be developed for addressing an energy-related emergency and decentralizing the error-base access points and user nodes. It is difficult to manage the power transmission from the different power sources to the IoT nodes and this pathway is often plagued with challenges. For mitigating the existing energy demand, one energy source is insufficient as it cannot provide sufficient power to the sensors. Therefore, a multisource EH system or hybrid EH system is currently under development. However, these systems require a lot of attention as they are not easy to implement. Similarly, hybrid energy systems and multiple sources require an advanced power management system. For this purpose, various researchers have recommended the use of a smart energy harvester for fulfilling the energy requirements of single or multiple-node sensors.

The maximum power point tracking (MPPT) accuracy and efficiency need to be improved for ensuring that energy is properly harvested. Better and intelligent battery charging processes and algorithms have been developed owing to the absence of smart EH processes. Some researchers are also investigating the auto $\mathrm{EH}$ selection process based on the presence of an energy source. Better IoT sensors which require a smaller area and multiple inputs which can target miniaturized devices need to be developed. This will make the IoT nodes very economical and feasible, instead of being bulky or more large-scale. Furthermore, because of the unavailability of wired energy sources for IoT devices, an IoT system has been developed for most battery-dependent devices. However, replacing the battery is a laborious and complex technique. Therefore, an ambient energy-based EH system is necessary. The availability and design of these ambient energy sources are dependent on the application and efficiency of the systems. Indoor and artificial light systems are used for increasing the availability of energy sources and for decreasing their dependence on batteries. The main aim of designing a self-generated energy framework for IoT devices and sensors is to convert the global preference for a battery-operated device to an independent EH system that solely depends on ambient power sources. Auto prediction of the user parameters makes the customer more comfortable and needs to be investigated further. Cheaper and readily available simulation tools can improve the research 
and application of IoT networks. Considering this, researchers have recommended the use of an open-source simulation environment.

The adoption of HBEH systems is not easy. Despite the adoption-based limitations, the body area network has become very popular amongst researchers. Furthermore, irregular and non-periodic energy generation is another limitation which has affected the wide-spread implementation of the HBEH process. An energy-efficient network protocol needs to be developed. Currently, millions of IoT devices and sensors are being used across the globe and must be disposed of. This issue also needs to be addressed. In the future, the disposal of IoT-related electronic waste (E-Waste) will create many issues. Therefore, immediate investigations, policies, and initiatives need to be developed for establishing an effective recycling protocol. IoT sensors and nodes are very reliable and sustainable and can be used for decreasing the spread of greenhouse gas emissions and harmful battery chemicals in the environment. For decreasing and controlling environmental pollution, the use of IoT devices based on ambient energy harvesting systems has been recommended.

\section{Conclusions}

Energy harvesting $(\mathrm{EH})$ systems used for IoT devices and sensors will require better EH processes for fulfilling the energy demands in the future. Many stockholders are considering prospective EH processes. In this paper, the prospective $\mathrm{EH}$ sources and strategies which can affect the energy generation process for IoT sensor nodes, have been reviewed. The energy harnessing levels, collective structure, estimation of the collected energy levels, and ability of a harvester of every class and subclass have also been investigated. Each energy source should display distinctive harnessing abilities and researchers should determine the extraordinary potential of different energy sources. Moreover, a detailed analysis of different EH models has been carried out for determining the potential energy cycles for tackling issues related to an interrupted power supply for powering IoT nodes. Finally, some open questions have been addressed regarding the non-exclusive energy harvesters which are used in different situations.

Author Contributions: Conceptualization, M.K.M, M.R., and N.A.; methodology, M.K.M. and M.R.; software, M.K.M. and M.R.; validation, M.K.M., M.R., and K.S.R; formal analysis, M.K.M. and M.R.; investigation, M.K.M., M.R, and S.K.T.; resources, N.A. and J.P.; data curation, M.K.M., M.R., and F.A.H.; writing-original draft preparation, M.K.M. and M.R.; writing-review and editing, M.K.M., M.R., M.S., K.S.R., J.P., and N.A.; visualization, M.K.M., M.R., and K.S.R.; supervision, N.A and J.P.; project administration, N.A.; funding acquisition, N.A. and J.P. All authors have read and agreed to the published version of the manuscript.

Funding: This research is financially supported by the grant code of LRGS/1/2019/UKM-UNITEN/6/2 from the Ministry of Higher Education (MoHE) of Malaysia. Moreover, BOLD2025 grants for laboratory support and publication support were received from Universiti Tenaga Nasional (@UNITEN), Malaysia.

Acknowledgments: The authors wish to thank the Ministry of Higher Education of Malaysia (MoHE) for providing the research grant with the code of LRGS/1/2019/UKM-UNITEN/6/2 to support this research. The authors also acknowledge the all-out laboratory support of Universiti Tenaga Nasional (@UNITEN), Malaysia, under the BOLD2025 program, as well as the contribution in publication support from the iRMC of the university.

Conflicts of Interest: The authors declare no conflict of interest.

\section{References}

1. Tzounis, A.; Katsoulas, N.; Bartzanas, T.; Kittas, C. Internet of Things in agriculture, recent advances and future challenges. Biosyst. Eng. 2017, 164, 31-48. [CrossRef]

2. Alavi, A.H.; Jiao, P.; Buttlar, W.G.; Lajnef, N. Internet of Things-enabled smart cities: State-of-the-art and future trends. Meas. J. Int. Meas. Confed. 2018, 129, 589-606. [CrossRef]

3. Samie, F.; Bauer, L.; Henkel, J. IoT technologies for embedded computing: A survey. In Proceedings of the 2016 International Conference on Hardware/Software Codesign and System Synthesis (CODES+ISSS), Pittsburgh, PA, USA, 2-7 October 2016. 
4. Pötsch, A.; Berger, A.; Springer, A. Efficient analysis of power consumption behaviour of embedded wireless IoT systems. In Proceedings of the 2017 IEEE International Instrumentation and Measurement Technology Conference, Turin, Italy, 22-25 May 2017; pp. 1-6.

5. Dhillon, P.K.; Kalra, S. Elliptic curve cryptography for real time embedded systems in IoT networks. In Proceedings of the 2016 5th International Conference on Wireless Networks and Embedded Systems (WECON), Rajpura, India, 14-16 October 2016; pp. 1-6.

6. Patil, N.; Ambatkar, S.; Kakde, S. IoT based smart surveillance security system using raspberry Pi. In Proceedings of the 2017 International Conference on Communication and Signal Processing (ICCSP), Chennai, India, 6-8 April 2017; pp. 344-348.

7. Sruthy, S.; George, S.N. WiFi enabled home security surveillance system using Raspberry Pi and IoT module. In Proceedings of the 2017 IEEE International Conference on Signal Processing, Informatics, Communication and Energy Systems (SPICES), Kollam, India, 8-10 August 2017; pp. 1-6.

8. Jyothi, S.N.; Vardhan, K.V. Design and implementation of real time security surveillance system using IoT. In Proceedings of the 2016 International Conference on Communication and Electronics Systems (ICCES), Coimbatore, India, 21-22 October 2016; pp. 1-5.

9. Nikolaidis, P.; Didic, A.; Mubeen, S.; Pei-Breivold, H.; Sandström, K.; Behnam, M. Applying Mitigation Mechanisms for Cloud-based Controllers in Industrial IoT Applications. In Proceedings of the Internet-of-Things Symposium. IoT Symposium, Amsterdam, The Netherlands, 4-9 October 2015.

10. Mubeen, S.; Nikolaidis, P.; DIdic, A.; Pei-Breivold, H.; Sandstrom, K.; Behnam, M. Delay Mitigation in Offloaded Cloud Controllers in Industrial IoT. IEEE Access 2017, 5, 4418-4430. [CrossRef]

11. Bardwell, M.; Wong, J.; Zhang, S.; Musilek, P. Design considerations for IoT-based PV charge controllers. In Proceedings of the 2018 IEEE World Congress on Services (SERVICES), San Francisco, CA, USA, 2-7 July 2018; pp. 59-60.

12. Sherly, J.; Somasundareswari, D. Internet of things based smart transportation systems. Int. Res. J. Eng. Technol. 2015, 2, 1207-1210.

13. Rathore, M.M.; Ahmad, A.; Paul, A.; Thikshaja, U.K. Exploiting real-time big data to empower smart transportation using big graphs. In Proceedings of the 2016 IEEE Region 10 Symposium (TENSYMP), Bali, Indonesia, 9-11 May 2016; pp. 135-139.

14. Neto, A.J.V.; Zhao, Z.; Rodrigues, J.J.P.C.; Camboim, H.B.; Braun, T. Fog-based crime-assistance in smart iot transportation system. IEEE Access 2018, 6, 11101-11111. [CrossRef]

15. Zeng, W.; Shu, L.; Li, Q.; Chen, S.; Wang, F.; Tao, X.-M. Fiber-Based Wearable Electronics: A Review of Materials, Fabrication, Devices, and Applications. Adv. Mater. 2014, 26, 5310-5336. [CrossRef] [PubMed]

16. Grady, S. Powering Wearable Technology and Internet of Everything Devices; Cymbet Corp: Elk River, MN, USA, 2014; Volume WP-72-10, pp. 1-17.

17. Nguyen Gia, T.; Sarker, V.K.; Tcarenko, I.; Rahmani, A.M.; Westerlund, T.; Liljeberg, P.; Tenhunen, H. Energy efficient wearable sensor node for IoT-based fall detection systems. Microprocess. Microsyst. 2018, 56, $34-46$. [CrossRef]

18. Arias, O.; Wurm, J.; Hoang, K.; Jin, Y. Privacy and security in internet of things and wearable devices. IEEE Trans. Multi Scale Comput. Syst. 2015, 1, 99-109. [CrossRef]

19. Mani, V.; Abhilasha; Gunasekhar. Iot based smart energy tracking system. Int. J. Appl. Eng. Res. 2017, 12, 5455-5462.

20. Mois, G.; Folea, S.; Sanislav, T. Analysis of Three IoT-Based Wireless Sensors for Environmental Monitoring. IEEE Trans. Instrum. Meas. 2017, 66, 2056-2064. [CrossRef]

21. Tellez, M.; El-Tawab, S.; Heydari, H.M. Improving the security of wireless sensor networks in an IoT environmental monitoring system. In Proceedings of the 2016 IEEE systems and information engineering design symposium (SIEDS), Charlottesville, VA, USA, 29 April 2016; pp. 72-77.

22. Alvarez-Campana, M.; López, G.; Vázquez, E.; Villagrá, V.A.; Berrocal, J. Smart CEI moncloa: An iot-based platform for people flow and environmental monitoring on a Smart University Campus. Sensors 2017, 17, 2856. [CrossRef] [PubMed]

23. Kalatzis, N.; Avgeris, M.; Dechouniotis, D.; Papadakis-Vlachopapadopoulos, K.; Roussaki, I.; Papavassiliou, S. Edge computing in iot ecosystems for uav-enabled early fire detection. In Proceedings of the 2018 IEEE International Conference on Smart Computing (SMARTCOMP), Taormina, Italy, 18-20 June 2018; pp. 106-114. 
24. Kumar Sharma, A.; Faiz Raza Ansari, M.; Firoz Siddiqui, M.; Ataullah Baig, M.; Noida, G. Iot Enabled Forest Fire Detection and Online Monitoring System (By Using Atmega 328-P Microcontroller). Int. J. Curr. Trends Eng. Res. 2017, 3, 50-54.

25. Muhammad, K.; Khan, S.; Elhoseny, M.; Hassan Ahmed, S.; Wook Baik, S. Efficient Fire Detection for Uncertain Surveillance Environment. IEEE Trans. Ind. Inform. 2019, 15, 3113-3122. [CrossRef]

26. Zhang, H.; Zhang, Z.; Zhang, L.; Yang, Y.; Kang, Q.; Sun, D. Object Tracking for a Smart City Using IoT and Edge Computing. Sensors 2019, 19, 1987. [CrossRef] [PubMed]

27. Koubaa, A.; Qureshi, B. DroneTrack: Cloud-Based Real-Time Object Tracking Using Unmanned Aerial Vehicles over the Internet. IEEE Access 2018, 6, 13810-13824. [CrossRef]

28. Anandhi, S.; Anitha, R.; Sureshkumar, V. IoT enabled RFID authentication and secure object tracking system for smart logistics. Wirel. Pers. Commun. 2019, 104, 543-560. [CrossRef]

29. Celesti, A.; Galletta, A.; Carnevale, L.; Fazio, M.; Lay-Ekuakille, A.; Villari, M. An IoT cloud system for traffic monitoring and vehicular accidents prevention based on mobile sensor data processing. IEEE Sens. J. 2017, 18, 4795-4802. [CrossRef]

30. Sukode, S.; Gite, S. Vehicle traffic congestion control \& monitoring system in iot. Int. J. Appl. Eng. Res. 2015, 10, 19513-19523.

31. Darbari, M.; Yagyasen, D.; Tiwari, A. Intelligent traffic monitoring using Internet of Things (IoT) with semantic Web. In Proceedings of the Emerging ICT for Bridging the Future-Proceedings of the 49th Annual Convention of the Computer Society of India (CSI); Springer: Berlin, Germany, 2015; Volume 1, pp. 455-462.

32. Dhingra, S.; Madda, R.B.; Patan, R.; Jiao, P.; Barri, K.; Alavi, A.H. Internet of things-based fog and cloud computing technology for smart traffic monitoring. Internet Things 2020, 100175, in press. [CrossRef]

33. Zamora-Izquierdo, M.A.; Santa, J.; Martínez, J.A.; Martínez, V.; Skarmeta, A.F. Smart farming IoT platform based on edge and cloud computing. Biosyst. Eng. 2019, 177, 4-17. [CrossRef]

34. Kale, A.P.; Sonavane, S.P. IoT based Smart Farming: Feature subset selection for optimized high-dimensional data using improved GA based approach for ELM. Comput. Electron. Agric. 2019, 161, 225-232. [CrossRef]

35. Jawad, H.M.; Nordin, R.; Gharghan, S.K.; Jawad, A.M.; Ismail, M. Energy-efficient wireless sensor networks for precision agriculture: A review. Sensors 2017, 17, 1781. [CrossRef] [PubMed]

36. Elhayatmy, G.; Dey, N.; Ashour, A.S. Internet of Things based wireless body area network in healthcare. In Internet of Things and Big Data Analytics toward Next-Generation Intelligence; Springer Science and Business Media LLC: Berlin, Germany, 2018; pp. 3-20.

37. Mainanwal, V.; Gupta, M.; Upadhayay, S.K. A survey on wireless body area network: Security technology and its design methodology issue. In Proceedings of the 2015 international conference on innovations in information, embedded and communication systems (ICIIECS), Coimbatore, India, 19-20 March 2015; pp. 1-5.

38. Hassan, M.M.; Lin, K.; Yue, X.; Wan, J. A multimedia healthcare data sharing approach through cloud-based body area network. Futur. Gener. Comput. Syst. 2017, 66, 48-58. [CrossRef]

39. Latré, B.; Braem, B.; Moerman, I.; Blondia, C.; Demeester, P. A survey on wireless body area networks. Wirel. Netw. 2011, 17, 1-18. [CrossRef]

40. Jacob Morgan A Simple Explanation Of "The Internet Of Things". Available online: https://www.forbes.com/ sites/jacobmorgan/2014/05/13/simple-explanation-internet-things-that-anyone-can-understand/\#23a45c0e1d09 (accessed on 13 April 2020).

41. Babar, M.; Rahman, A.; Arif, F.; Jeon, G. Energy-harvesting based on internet of things and big data analytics for smart health monitoring. Sustain. Comput. Inform. Syst. 2018, 20, 155-164. [CrossRef]

42. Akan, O.B.; Cetinkaya, O.; Koca, C.; Ozger, M. Internet of Hybrid Energy Harvesting Things. IEEE Internet Things J. 2018, 5, 736-746. [CrossRef]

43. Kortuem, G.; Kawsar, F.; Sundramoorthy, V.; Fitton, D. Smart objects as building blocks for the internet of things. IEEE Internet Comput. 2010, 14, 44-51. [CrossRef]

44. Shaikh, F.K.; Zeadally, S. Energy harvesting in wireless sensor networks: A comprehensive review. Renew. Sustain. Energy Rev. 2016, 55, 1041-1054. [CrossRef]

45. Ryu, H.; Yoon, H.J.; Kim, S.W. Hybrid Energy Harvesters: Toward Sustainable Energy Harvesting. Adv. Mater. 2019, 31, 1-19. [CrossRef]

46. Lee, J.H.; Kim, J.; Kim, T.Y.; Al Hossain, M.S.; Kim, S.W.; Kim, J.H. All-in-one energy harvesting and storage devices. J. Mater. Chem. A 2016, 4, 7983-7999. [CrossRef] 
47. Zergoune, Z.; Kacem, N.; Bouhaddi, N. On the energy localization in weakly coupled oscillators for electromagnetic vibration energy harvesting. Smart Mater. Struct. 2019, 28, 07LT02. [CrossRef]

48. Drezet, C.; Kacem, N.; Bouhaddi, N. Design of a nonlinear energy harvester based on high static low dynamic stiffness for low frequency random vibrations. Sens. Actuators A Phys. 2018, 283, 54-64. [CrossRef]

49. Sari, I.; Balkan, T.; Kulah, H. An electromagnetic micro power generator for wideband environmental vibrations. Sens. Actuators A Phys. 2008, 145-146, 405-413. [CrossRef]

50. Mann, B.P.; Sims, N.D. Energy harvesting from the nonlinear oscillations of magnetic levitation. J. Sound Vib. 2009, 319, 515-530. [CrossRef]

51. Champagne, C.; Weiss, L. Performance analysis of a miniature free piston expander for waste heat energy harvesting. Energy Convers. Manag. 2013, 76, 883-892. [CrossRef]

52. Lee, S.W.; Yang, Y.; Lee, H.-W.; Ghasemi, H.; Kraemer, D.; Chen, G.; Cui, Y. An electrochemical system for efficiently harvesting low-grade heat energy. Nat. Commun. 2014, 5, 1-6. [CrossRef]

53. Tran, L.G.; Cha, H.K.; Park, W.T. RF power harvesting: A review on designing methodologies and applications. Micro Nano Syst. Lett. 2017, 5, 3. [CrossRef]

54. Zungeru, A.M.; Ang, L.-M.; Prabaharan, S.; Seng, K.P. Radio frequency energy harvesting and management for wireless sensor networks. In Green Mobile Devices and Networks: Energy Optimization and Scavenging Techniques; CRC Press: New York, NY, USA, 2012; pp. 341-368.

55. Fleck, J. Development and establishment in artificial intelligence. In Scientific Establishments and Hierarchies; Springer: Berlin, Germany, 1982; pp. 169-217.

56. Lee, I.; Lee, K. The Internet of Things (IoT): Applications, investments, and challenges for enterprises. Bus. Horiz. 2015, 58, 431-440. [CrossRef]

57. Chandrasekaran, S.; Bowen, C.; Roscow, J.; Zhang, Y.; Dang, D.K.; Kim, E.J.; Misra, R.D.K.; Deng, L.; Chung, J.S.; Hur, S.H. Micro-scale to nano-scale generators for energy harvesting: Self powered piezoelectric, triboelectric and hybrid devices. Phys. Rep. 2019, 792, 1-33. [CrossRef]

58. Shivarama Krishna, K.; Sathish Kumar, K. A review on hybrid renewable energy systems. Renew. Sustain. Energy Rev. 2015, 52, 907-916. [CrossRef]

59. Shi, Q.; He, T.; Lee, C. More than energy harvesting-Combining triboelectric nanogenerator and flexible electronics technology for enabling novel micro-/nano-systems. Nano Energy 2019, 57, 851-871. [CrossRef]

60. Selvan, K.V.; Mohamed Ali, M.S. Micro-scale energy harvesting devices: Review of methodological performances in the last decade. Renew. Sustain. Energy Rev. 2016, 54, 1035-1047. [CrossRef]

61. Keertikumar, M.; Shubham, M.; Banakar, R.M. Evolution of IoT in smart vehicles: An overview. In Proceedings of the 2015 International Conference on Green Computing and Internet of Things (ICGCIoT), Noida, India, 8-10 October 2015; pp. 804-809.

62. Company, R. Experiments Involving Microwave Beam to Power and Position Helicopter. IEEE Trans. Aerosp. Electron. Syst. 1969, 5, 692-702.

63. Kymissis, J.; Kendall, C.; Paradiso, J.; Gershenfeld, N. Parasitic power harvesting in shoes. In Proceedings of the Digest of Papers. Second International Symposium on Wearable Computers (Cat. No. 98EX215), Pittsburgh, PA, USA, 19-20 October 1998; pp. 132-139.

64. Roundy, S.; Wright, P.K. A piezoelectric vibration based generator for wireless electronics. Smart Mater. Struct. 2004, 13, 1131. [CrossRef]

65. Lallart, M.; Cottinet, P.; Guyomar, D.; Lebrun, L. Electrostrictive polymers for mechanical energy harvesting. J. Polym. Sci. Part B Polym. Phys. 2012, 50, 523-535. [CrossRef]

66. Tan, S.-S.; Liu, C.-Y.; Yeh, L.-K.; Chiu, Y.-H.; Lu, M.S.-C.; Hsu, K.Y.J. An integrated low-noise sensing circuit with efficient bias stabilization for CMOS MEMS capacitive accelerometers. IEEE Trans. Circuits Syst. I Regul. Pap. 2011, 58, 2661-2672. [CrossRef]

67. Iannacci, J. Microsystem based Energy Harvesting (EH-MEMS): Powering pervasivity of the Internet of Things (IoT)—A review with focus on mechanical vibrations. J. King Saud Univ. Sci. 2019, 31, 66-74. [CrossRef]

68. Khare, V.; Nema, S.; Baredar, P. Solar-wind hybrid renewable energy system: A review. Renew. Sustain. Energy Rev. 2016, 58, 23-33. [CrossRef]

69. Sinha, S.; Chandel, S.S. Review of software tools for hybrid renewable energy systems. Renew. Sustain. Energy Rev. 2014, 32, 192-205. [CrossRef] 
70. Khan, M.A.M.; Rehman, S.; Al-Sulaiman, F.A. A hybrid renewable energy system as a potential energy source for water desalination using reverse osmosis: A review. Renew. Sustain. Energy Rev. 2018, 97, 456-477. [CrossRef]

71. Kasseris, E.; Samaras, Z.; Zafeiris, D. Optimization of a wind-power fuel-cell hybrid system in an autonomous electrical network environment. Renew. Energy 2007, 32, 57-79. [CrossRef]

72. Bernal-Agustín, J.L.; Dufo-López, R. Simulation and optimization of stand-alone hybrid renewable energy systems. Renew. Sustain. Energy Rev. 2009, 13, 2111-2118. [CrossRef]

73. Liu, Y.; Li, Z.; Li, H.; Wang, Y.; Li, X.; Ma, K.; Li, S.; Chang, M.F.; John, S.; Xie, Y.; et al. Ambient energy harvesting nonvolatile processors: From circuit to system. In Proceedings of the 52nd Annual Design Automation Conference, San Francisco, CA, USA, 8-12 June 2015; pp. 1-6.

74. Bhandari, B.; Lee, K.T.; Lee, G.Y.; Cho, Y.M.; Ahn, S.H. Optimization of hybrid renewable energy power systems: A review. Int. J. Precis. Eng. Manuf. Green Technol. 2015, 2, 99-112. [CrossRef]

75. Pérez-Collazo, C.; Greaves, D.; Iglesias, G. A review of combined wave and offshore wind energy. Renew. Sustain. Energy Rev. 2015, 42, 141-153. [CrossRef]

76. del Real, A.J.; Arce, A.; Bordons, C. Optimization strategy for element sizing in hybrid power systems. J. Power Sources 2009, 193, 315-321. [CrossRef]

77. Vosen, S.R.; Keller, J.O. Hybrid energy storage systems for stand-alone electric power systems: Optimization of system performance and cost through control strategies. Int. J. Hydrogen Energy 1999, 24, 1139-1156. [CrossRef]

78. Garg, N.; Garg, R. Energy harvesting in IoT devices: A survey. In Proceedings of the 2017 International Conference on Intelligent Sustainable Systems (ICISS), Palladam, India, 7-8 December 2017; pp. 127-131.

79. Kulatunga, C.; Bhargava, K.; Vimalajeewa, D.; Ivanov, S. Cooperative in-network computation in energy harvesting device clouds. Sustain. Comput. Informatics Syst. 2017, 16, 106-116. [CrossRef]

80. Shao, H.; Tsui, C.Y.; Ki, W.H. A micro power management system and maximum output power control for solar energy harvesting applications. In Proceedings of the 2007 International Symposium on Low Power Electronics and Design (ISLPED '07), Portland, OR, USA, 27-29 August 2007; pp. 298-303.

81. Zeng, G.; Bahk, J.-H.; Bowers, J.E.; Zide, J.M.O.; Gossard, A.C.; Bian, Z.; Singh, R.; Shakouri, A.; Kim, W.; Singer, S.L. Er As:(In Ga As) 1- x (In Al As) x alloy power generator modules. Appl. Phys. Lett. 2007, 91, 263510. [CrossRef]

82. Khvostikov, V.P.; Khvostikova, O.A.; Gazaryan, P.Y.; Sorokina, S.V.; Potapovich, N.S.; Malevskaya, A.V.; Kaluzhniy, N.A.; Shvarts, M.Z.; Andreev, V.M. Photovoltaic cells based on GaSb and Ge for solar and thermophotovoltaic applications. J. Sol. Energy Eng. 2007, 129, 291-297. [CrossRef]

83. Lin, D.; Guo, M.S.; Lam, K.H.; Kwok, K.W.; Chan, H.L.W. Lead-free piezoelectric ceramic (K0. 5Na0. 5) NbO3 with $\mathrm{MnO} 2$ and K5. 4Cu1. 3Ta10O29 doping for piezoelectric transformer application. Smart Mater. Struct. 2008, 17, 35002. [CrossRef]

84. Fan, Y.; Sharbrough, E.; Liu, H. Quantification of the internal resistance distribution of microbial fuel cells. Environ. Sci. Technol. 2008, 42, 8101-8107. [CrossRef] [PubMed]

85. Pykälä, M.-L.; Sipilä, K.; Mroueh, U.-M.; Wahlström, M.; Huovila, H.; Tynell, T.; Tervo, J. Susterel Energy Harvesting Roadmap for Societal Applications; VTT Research Report VTT: Espoo, Finland, 2012.

86. Hayes, M. Synergies between Energy Harvesting and Power Electronics Slides. Available online: https: //resourcecenter.ieee-pels.org/webinars/PELSWEB010202016.html (accessed on 23 March 2020).

87. Franciscatto, B. Design and Implementation of a New Low-Power Consumption DSRC Transponder. Ph.D. Thesis, Université de Grenoble, Saint-Martin-d'Hères, France, 2014.

88. Shirvanimoghaddam, M.; Shirvanimoghaddam, K.; Abolhasani, M.M.; Farhangi, M.; Zahiri Barsari, V.; Liu, H.; Dohler, M.; Naebe, M. Towards a Green and Self-Powered Internet of Things Using Piezoelectric Energy Harvesting. IEEE Access 2019, 7, 94533-94556. [CrossRef]

89. Vullers, R.J.M.; Van Schaijk, R.; Visser, H.J.; Penders, J.; Van Hoof, C. Energy harvesting for autonomous wireless sensor networks. IEEE Solid State Circuits Mag. 2010, 2, 29-38. [CrossRef]

90. Ünlü, F.; Wawrla, L.; Dìaz, A. Energy Harvesting Technologies for Iot Edge Devices; 4E, Int. Energy Agency: Paris, France, 2018.

91. Alsharif, M.H.; Kim, S. SS symmetry Energy Harvesting Techniques for Wireless Sensor Networks/Radio-Frequency Identification: A Review. Symmetry 2019, 11, 865. [CrossRef] 
92. Dargie, W. Principles and Applications of Ubiquitous Sensing, 1st ed.; John Wiley \& Sons: Hoboken, NJ, USA, 2017; pp. 253-277. ISBN 1119091349.

93. Cetinkaya, O.; Akan, O.B. Electric-field energy harvesting in wireless networks. IEEE Wirel. Commun. 2017, 24, 34-41. [CrossRef]

94. Zhao, X.; Keutel, T.; Baldauf, M.; Kanoun, O. Energy harvesting for a wireless-monitoring system of overhead high-voltage power lines. IET Gener. Transm. Distrib. 2013, 7, 101-107. [CrossRef]

95. Sudevalayam, S.; Kulkarni, P. Energy harvesting sensor nodes: Survey and implications. IEEE Commun. Surv. Tutorials 2010, 13, 443-461. [CrossRef]

96. Starner, T. Human-powered wearable computing. IBM Syst. J. 1996, 35, 618-629. [CrossRef]

97. Carreon-Bautista, S.; Huang, L.; Sanchez-Sinencio, E.; Fellow, L. An Autonomous Energy Harvesting Power Management Unit with Digital Regulation for IoT Applications. IEEE J. Solid State Circuits 2016, 51, 1-18. [CrossRef]

98. Penella-López, M.T.; Gasulla-Forner, M. Powering Autonomous Sensors; Springer: Berlin, Germany, 2011; ISBN 978-94-0071-573-8.

99. Renewable, I.; Agency, E. Renewable Energy Statistics 2019 Statistiques De Énergie Renouvelable 2019 Estadísticas De Energía; IRENA: Abu Dhabi, UAE, 2019; ISBN 978-92-9260-137-9.

100. Adu-Manu, K.S.; Adam, N.; Tapparello, C.; Ayatollahi, H.; Heinzelman, W. Energy-harvesting wireless sensor networks (EH-WSNs): A review. ACM Trans. Sens. Networks 2018, 14, 1-50. [CrossRef]

101. Fahrenbruch, A.; Bube, R. Fundamentals of Solar Cells: Photovoltaic Solar Energy Conversion; Elsevier: Cambridge, MA, USA, 2012; ISBN 032-31-453-88.

102. Morais, R.; Matos, S.G.; Fernandes, M.A.; Valente, A.L.G.; Soares, S.F.S.P.; Ferreira, P.; Reis, M. Sun, wind and water flow as energy supply for small stationary data acquisition platforms. Comput. Electron. Agric. 2008, 64, 120-132. [CrossRef]

103. Bhuvaneswari, P.T.V.; Balakumar, R.; Vaidehi, V.; Balamuralidhar, P. Solar energy harvesting for wireless sensor networks. In Proceedings of the 2009 First International Conference on Computational Intelligence, Communication Systems and Networks, Indore, India, 23-25 July 2009; pp. 57-61.

104. Kobbekaduwa, K.P.V.B. Modelling and Analysis of Thermoelectric Generation of Materials Using Matlab/Simulink. Int. J. Energy Power Eng. 2016, 5, 97. [CrossRef]

105. Dalala, Z.M.; Saadeh, O.; Bdour, M.; Zahid, Z.U. A new maximum power point tracking (MPPT) algorithm for thermoelectric generators with reduced voltage sensors count control. Energies 2018, 11, 1826. [CrossRef]

106. Curie, J.; Curie, P. Development by pressure of polar electricity in hemihedral crystals with inclined faces. Bull. Soc. Min. Fr. 1880, 3, 90.

107. Curie, J.; Curie, P. Contractions and expansions produced by voltages in hemihedral crystals with inclined faces. C. R. 1881, 93, 1137-1140.

108. Jiao, P.; Egbe, K.J.I.; Xie, Y.; Nazar, A.M.; Alavi, A.H. Piezoelectric sensing techniques in structural health monitoring: A state-of-the-art review. Sensors 2020, 20, 3730. [CrossRef]

109. Liu, Y.; Tian, G.; Wang, Y.; Lin, J.; Zhang, Q.; Hofmann, H.F. Active Piezoelectric Energy Harvesting: General Principle and Experimental Demonstration. J. Intell. Mater. Syst. Struct. 2009, 20, 575-585.

110. Yang, Y.; Guo, W.; Pradel, K.C.; Zhu, G.; Zhou, Y.; Zhang, Y.; Hu, Y.; Lin, L.; Wang, Z.L. Pyroelectric nanogenerators for harvesting thermoelectric energy. Nano Lett. 2012, 12, 2833-2838. [CrossRef]

111. Han, N.; Ho, J.C. One-Dimensional Nanomaterials for Energy Applications. In Nanocrystalline Materials, 2nd ed.; Elsevier: Amsterdam, The Netherlands, 2014; ISBN 978-01-2407-796-6.

112. Fan, F.R.; Tian, Z.Q.; Lin Wang, Z. Flexible triboelectric generator. Nano Energy 2012, 1, 328-334. [CrossRef]

113. Wang, L.; Yuan, F.G. Vibration energy harvesting by magnetostrictive material. Smart Mater. Struct. 2008, $17,45009$. [CrossRef]

114. Torres, E.; Ponce, P.; Molina, A. Electromagnetic induction generator toward energy harvesting for dynamic systems. In Proceedings of the 2017 IEEE International Conference on Industrial Technology (ICIT), Toronto, ON, Canada, 22-25 March 2017; pp. 418-422.

115. Ambrozkiewicz, B.; Litak, G.; Wolszczak, P. Modelling of electromagnetic energy harvester with rotational pendulum using mechanical vibrations to scavenge electrical energy. Appl. Sci. 2020, 10, 671. [CrossRef]

116. Li, K.; He, X.; Wang, X.; Jiang, S. A Nonlinear Electromagnetic Energy Harvesting System for Self-Powered Wireless Sensor Nodes. J. Sens. Actuator Netw. 2019, 8, 18. [CrossRef] 
117. Zhu, S.; Shen, W.; Xu, Y. Linear electromagnetic devices for vibration damping and energy harvesting: Modeling and testing. Eng. Struct. 2012, 34, 198-212. [CrossRef]

118. Luo, Q.; He, X.; Jiang, S.; Wang, X. Impact-based electromagnetic energy harvester with high output voltage under low-level excitations. Energies 2017, 10, 1848. [CrossRef]

119. Zhang, H.; Corr, L.R.; Ma, T. Effects of electrical loads containing non-resistive components on electromagnetic vibration energy harvester performance. Mech. Syst. Signal Process. 2018, 101, 55-66. [CrossRef]

120. Aelterman, P.; Rabaey, K.; Clauwaert, P.; Verstraete, W. Microbial fuel cells for wastewater treatment. Water Sci. Technol. 2006, 54, 9-15. [CrossRef]

121. Ahn, Y.; Logan, B.E. Effectiveness of domestic wastewater treatment using microbial fuel cells at ambient and mesophilic temperatures. Bioresour. Technol. 2010, 101, 469-475. [CrossRef]

122. Ghangrekar, M.M.; Shinde, V.B. Performance of membrane-less microbial fuel cell treating wastewater and effect of electrode distance and area on electricity production. Bioresour. Technol. 2007, 98, 2879-2885. [CrossRef]

123. Oh, S.; Logan, B.E. Hydrogen and electricity production from a food processing wastewater using fermentation and microbial fuel cell technologies. Water Res. 2005, 39, 4673-4682. [CrossRef]

124. Le, T.; Mayaram, K.; Fiez, T. Efficient Far-Field Radio Frequency Energy Harvesting for Passively Powered Sensor Networks. IEEE J. Solid State Circuits 2008, 43, 1287-1302. [CrossRef]

125. Li, L.; Zhang, X.; Song, C.; Huang, Y. Progress, challenges, and perspective on metasurfaces for ambient radio frequency energy harvesting. Appl. Phys. Lett. 2020, 116, 60501. [CrossRef]

126. Orrego, S.; Shoele, K.; Ruas, A.; Doran, K.; Caggiano, B.; Mittal, R.; Kang, S.H. Harvesting ambient wind energy with an inverted piezoelectric flag. Appl. Energy 2017, 194, 212-222. [CrossRef]

127. Nabavi, S.; Zhang, L. Portable wind energy harvesters for low-power applications: A survey. Sensors 2016, 16, 1101. [CrossRef] [PubMed]

128. Choi, J.; Jung, I.; Kang, C. A brief review of sound energy harvesting. Nano Energy 2018, 56, 169-183. [CrossRef]

129. Yuan, M.; Cao, Z.; Luo, J.; Chou, X. Recent developments of acoustic energy harvesting: A review. Micromachines 2019, 10, 48. [CrossRef]

130. Awal, M.R.; Jusoh, M.; Sabapathy, T.; Kamarudin, M.R.; Rahim, R.A. State-of-the-Art Developments of Acoustic Energy Transfer. Int. J. Antennas Propag. 2016, 2016, 1-14. [CrossRef]

(C) 2020 by the authors. Licensee MDPI, Basel, Switzerland. This article is an open access article distributed under the terms and conditions of the Creative Commons Attribution (CC BY) license (http://creativecommons.org/licenses/by/4.0/). 